\title{
Allocating police resources while limiting racial inequality ${ }^{*}$
}

Andrew P. Wheeler ${ }^{1, * *}$

*Data and code to replicate the findings can be obtained from

https://www.dropbox.com/s/8vlw0zrmxfulbn3/Anon_AllocatingInequality.zip?dl=0.

**Corresponding author, email: apwheele@gmail.com

1. School of Economic, Political, and Policy Sciences - Program in Criminology and Criminal Justice

The University of Texas at Dallas

800 West Campbell Road, Mail Station GR 31

Richardson, Texas 75080-3021

Andrew P. Wheeler is an Assistant Professor of criminology at the University of Texas at Dallas in the School of Economic, Political, and Policy Sciences. His research focuses on the spatial analysis of crime at micro places, evaluating crime reduction policies by police departments, and practical problems faced by crime analysts.

I thank Nadine Connell for feedback on earlier versions of this work. 
Title: Allocating police resources while limiting racial inequality

Abstract: Police targeting hot spots of crime tends to disproportionately burden minorities via stops and arrests. This work attempts to reduce disproportionate minority contact by formulating a crime hot spots spatial allocation strategy for police that prioritizes areas of high crime, but constrains the targeted hot spots given different levels of acceptable racial inequality. This racial inequality constraint is measured as the proportion of minorities likely to be stopped in those areas prioritized by police. Using data on stops and crime in New York City, I show that police stops can be more equitably distributed according to race, but there are fundamental trade-offs. One cannot gain a racial distribution of stops proportionately equal to the residential population without large decreases in the efficiency of targeting high crime areas. More modest gains can be had though in reducing the proportion of minorities stopped while still targeting high crime locations.

Keywords: hot-spots, racial-bias, predictive-policing, linear-programming

Data and code to replicate the analysis can be downloaded from

https://www.dropbox.com/s/8vlw0zrmxfulbn3/Anon_AllocatingInequality.zip?dl=0.

\section{Introduction}

Hot spots policing often comes with questions of racial equity, as minority communities often bear the brunt of increased police invasiveness (Fagan, 2017b). In particular, spatially allocating more police presence at hot spots of crime or high crime neighborhoods has the likely consequence of increasing disproportionate minority contact (DMC) and contributing to racial disparity in police stops and arrests, as high crime locations tend to be correlated with minority and disadvantaged populations (Shaw \& McKay, 1969; Sampson \& Wilson, 1995; Wilson, 1987). 
This has implications not only for racial disparity in police contact with citizens, but for various later points in the criminal justice system. Since an arrest by police is the first point at which individuals are introduced into the criminal justice system, racial disparities in arrests are likely to continue throughout the rest of the criminal justice system, such as via those incarcerated or under formal supervision (Goldkamp \& Vîlcicã, 2008).

This would seem to present an inescapable problem. It seems logical to focus police resources where there is the most crime. Both historical sources of police management have suggested allocating more resources to higher crime areas (Wilson, 1957), and more recently hot spots policing has proven to be successful at reducing crime in a wide variety of interventions (Braga, Papachristos, \& Hureau, 2014). So how does one target high crime areas, while balancing out concerns about racial equity and fairness?

I attempt to solve this problem by formulating a linear program to spatially allocate police resources to maximize police activity in high crime areas, while limiting the amount of racial disparity one would expect in contacts with the police. Currents solutions only focus on the types of policing that occurs within hot spots, which although may improve police community relations (Braga, Brunson, Drakulich, 2019; Lum \& Nagin, 2017; Owens et al., 2018) are unlikely to reduce DMC and the disparate impact that occurs with more criminal justice contact (Brayne, 2014). As opposed to focusing on what the police do in hot spots, this article proposes a proactive policing strategy that is consistent with a hot spots policing approach, but still takes into consideration how the spatial distribution of police resources can either exacerbate or mitigate DMC. Limiting the level of DMC can be a constraint placed on the spatial allocation system, by noting what proportion different racial groups tend to be stopped at different 
locations. One can then set a constraint on the allowable amount of racial disparity one is willing to tolerate in police contacts that is likely to occur under that hot spots policing strategy.

For an example, imagine a police department has a choice between two hot spots: one in which 30 robberies (area A) are predicted to occur in the following year versus an area with an expected 28 robberies (area B). All contemporary hot spots policing strategies would choose area A to focus resources on. But also imagine in area A that over $90 \%$ of police stops would be expected to be of minorities, and in area B only $70 \%$ stops would be expected to be of minorities. If one accepts the premise that reducing DMC is a reasonable goal for policing in-and-of-itself, then the trade-off in allocating resources to hot spot B, even though it has fewer predicted crimes than area A, seems reasonable, given the decrease in predicted crime from area A to area B is small.

This intuition of a reasonable trade-off is codified into the linear program to allocate resources to crime hot spots, while constraining the acceptable level of DMC expected to occur. Using data on pedestrian stops and violent crimes in New York City, I illustrate the procedure and quantify the trade-off in targeting not the highest crime locations given different minority stopped constraints.

\section{Fairness in Allocating Police Resources}

A question that needs to be addressed by policing scholars is whether the racial distribution of contacts with the police should factor into police decision making. That is, should decisions about where and when proactive police resources are deployed be race-blind? Relying strictly on race-blind predictive algorithms to allocate resources has the potential to exacerbate racial disparity (Brayne, 2017; Hardt, Price, \& Srebro, 2016; Ensign et al., 2018). A race-blind 
algorithm does not necessarily result in race-equal outcomes, as various structural differences in the lives of minorities can manifest themselves in ways that are included in the predictive models. These structural differences, such as living in poverty and in areas of persistently high levels of crime, can indirectly create large racial disparities even if race is not directly codified into the hot spots allocation algorithm. This suggests that simply ignoring race does not result in an algorithm being race-blind (Corbett-Davies et al., 2017; Eckhouse et al., 2019), and explicitly incorporating race into police decision making can actually result in more fair and efficient outcomes (Kleinberg et al., 2018).

The majority of prior analysis of fairness in policing has focused on fairness in treatment, with the research typically focusing on racial bias in officer decision making. Such research designs have examined individual level officer decision making in who they stop (Ridgeway \& MacDonald, 2009), the use-of-force (Terrill, 2005), or the decision to arrest (Worden, 1989). These have often relied on different quasi-experimental designs, such as the hit rates test (Coviello \& Persico, 2015), examining traffic stops in daylight versus nighttime (Grogger \& Ridgeway, 2006), or using different benchmarks (Miller, le Masurier, \& Wicks, 2000; Tregle, Nix, \& Alpert, 2019) to assess racial bias in how police treat minorities.

While such assessments are useful for monitoring whether police agencies are potentially racially biased in their decision making (MacDonald \& Braga, 2018; Tillyer, Engel, \& Wooldredge, 2008), they fall short in two particular aspects. One, simply telling a police department they are racially biased in decision making does not provide an actionable strategy for the police department to reduce such disparity. Second, even if police are not racially biased in how they treat individuals, equality of treatment does not necessarily equate to equality in outcomes. 
Beyond moral arguments, there are two main reasons why criminologists are interested in fairness in the criminal justice system. One, the concept of fairness is intimately tied into legitimacy (Tyler, 2017; Tyler, Fagan, \& Geller, 2014). Increasing perceptions of fairness is then expected to have downstream effects of the community cooperating with police, thus making investigations more effective (Braga et al., 2019).

Prior evaluations have addressed the fact that hot spots strategies do not appear to result in additional negative sentiment towards the police (Ratcliffe et al., 2015; Weisburd et al., 2011). Other recent work focuses on what police do at hot spots to reduce crime, in particular strategies focusing on problem-oriented policing approaches and procedural justice are less likely to result in negative community impressions (Braga et al., 2019; Owens et al., 2018). While encouraging police to be procedurally just in their encounters with the public is no doubt a good thing, there is scant evidence that improving procedural justice has resulted in improved police-citizen relations (Nagin \& Telep, 2017; Worden \& McLean, 2017). It is also the case that problem oriented approaches in policing tend to devolve into traditional policing tactics, such as focusing on stops and arrests in response to a particular problem (Braga \& Bond, 2008).

Being procedurally just in encounters with police is related to the idea of equality of treatment. All individuals should be treated equally, invariant to extra-legal characteristics such as race. The second reasons criminologists have been interested in fairness in police behavior, the extent to which a formal label results in negative long term consequences, is more closely tied to equality of outcomes. This line of research has been focused on how DMC subsequently produces negative consequences, for both individuals touched by the criminal justice system, as well as broader societal impacts. 
At the individual level, formal labelling by the criminal justice system results in negative consequences, such as the ability to gain employment (Pager, 2003). Even absent an arrest, simply being stopped by the police appears to prompt individuals to avoid different social institutions (Brayne, 2014; Lerman \& Weaver, 2013). At the aggregate level, such police contacts, warrants, and arrests have become so prevalent in particular minority neighborhoods they appear to have influenced overall levels of social control, and subsequently promoted more criminal behavior (Clear, 2008; Fagan, West, \& Holland, 2002; Goldkamp \& Vîlcicã, 2008; Hannon \& DeFina, 2012; Morenoff \& Harding, 2014).

While hot spots policing is not inconsistent with procedural justice, it does have direct implications for contact with the criminal justice system (Kochel, 2011). Even if officers are always procedurally just in their encounters with the public, this will not mitigate the negative side effects that formal labelling has. Even if a police department employs problem oriented policing tactics at hot spots of crime, places that have additional police officers will stop and arrest more individuals in those areas. The algorithm I propose here is one way navigate a data driven hot spots policing strategy, while mitigating the potential for such a strategy to increase DMC.

\section{Predictive Criminology and Disparate Impact}

Several prior examples of predictive algorithms that result in racially disparate outcomes in the criminal justice system are readily available, although most to date have focused on racial disparity in particular sentencing or community supervision practices. For example, Angwin et al. (2016) discuss how the COMPAS predictive algorithm for assigning pre- or post-trial risk status produces a larger number of false positives for minorities than for white individuals. Such 
an outcome can occur even if race is not included in the predictive model (Hardt, Price, \& Srebro, 2016). This is not necessarily a damning critique of the use of predictive algorithms though. If one can identify what unfair outcomes one wishes to avoid, it can be incorporated into the decision making process for how the information is used, or into the predictive algorithm itself (Corbett-Davies et al., 2017; Kleinberg et al., 2018). Deciding what is fair though is a difficult task - fairness along some particular continuum inevitably involves trade-offs with some other metric (Berk, 2016; Mohler et al., 2018; Ridgeway, 2017b).

Actuarial tools to make sentencing and parole decisions have been used for nearly 100 years (Harcourt, 2007). Many of these practices, such as three strike laws and mandatory minimum sentences, were expected to reduce the potential for racial bias in decision making by limiting the discretion of different criminal justice actors. Three strikes would apply equally whether you were white or a minority. They were also motivated by well-established statistical patterns in criminal behavior - in particular that prior offenders are more likely to commit future offenses (Spelman, 1995). But such policies had the unintended consequence of greatly expanding the prison population (Stemen \& Rengifo, 2011) and producing incredible numbers of minorities in American prisons (Petit \& Western, 2004).

It is possible that predictive policing algorithms, either those identifying spatial areas of increased crime risk, or estimates of individual risk (Saunders, Hunt, \& Hollywood, 2016), could result in similar unintended consequences that disproportionately impact minority individuals and communities (Brayne, 2017; Cohen, 2017). Lum \& Isaac (2016) give the hypothetical example of spatially allocating police to predicted hot spots of drug crimes. This has the problem that drug crimes are not objectively measured, but are mostly brought to light by prior arrests. Thus the behavior of the police can significantly bias the system to continually target areas 
where police previously arrested many individuals. Those areas are not necessarily where most drug crimes occur, but may be locations where subjective perceptions of crime and disorder are higher (Sampson \& Raudenbush, 2004). Such a feedback loop can perpetuate racial disparity in who is targeted by the police, as the future predicted hot spots will always be where police previously focused attention on.

A simple response to this is that a police department should use more objective measures of crime activity, such as crime with reported victims (Baumer, 2002) or gun shots via sensors (Loeffler \& Flaxman, 2018). A prior analysis of arrests in areas targeted by a predictive policing system did not experience elevated arrests of minorities compared to control locations (Brantingham, Valasik, \& Mohler, 2018). But a simple example can illustrate how a hot spots predictive policing system can exacerbate $\mathrm{DMC}$ - even if a police department only targets areas of objectively high crime.

The majority of predictive policing systems target a select number of locations that have the highest level of risk (Caplan, Kennedy, \& Miller, 2011; Mohler et al., 2015). This is quintessentially what hot spots policing is - disproportionately targeting a subset of places that disproportionately contribute to crime (Weisburd, 2015). If all of those selected high crime locations tend to have a large proportion of minorities, it is very likely that hot spots policing will lead to higher proportions of minority stops and arrests, above and beyond traditional reactive policing.

Consider an example of a city with two neighborhoods, A and B. Neighborhood A is 100 percent minority citizens, and neighborhood B is 100 percent white. Say also that A has a five times higher crime rate than $\mathrm{B}$, and this is also reflected in the stop rates, with neighborhood $\mathrm{A}$ having 500 stops per year, and neighborhood B having 100 stops per year. If the police 
department then decides to target additional resources to particular hot spots, those hot spots are likely to be contained within neighborhood A. Since neighborhood A is all minorities, any extra police resources will be likely to increase the number of minorities stopped, say an additional 50 stops per year. In the original purely reactive system, the stop rates for minority and white citizens simply reflected the overall crime rate in their respective neighborhoods, with minorities having a stop rate five times that of white citizens. With the addition of the hot spots patrols, it resulted in an additional 50 minorities stopped, so created a disparity where stop rates of minorities are 5.5 times that of whites, slightly larger than the crime rate between the races would predict. More stops will inevitably lead to more arrests, and so racial disparity in stops is likely to propagate to disparities at later points in the criminal justice system. While this is a simple hypothetical example, there is nothing essential about the current values chosen. All that is needed is police to allocate more resources in particular hot spots, and those hot spots have a higher proportion of minorities.

One might counter that, in the long run, in such a system minorities should reduce their crime rate in response to the extra diverted resources. Such a change in behavior would be very unlikely to occur quickly, and it is questionable whether it would occur at all (Barbe \& Horrace, 2012; Engel \& Tillyer, 2008; Harcourt, 2007; Kennedy, 1996; Pickett \& Roche, 2016). The short run disparity though can have negative externalities in those minority neighborhoods (as discussed in the 'Fairness in Allocating Police Resources' section).

Limiting police resources in certain areas no doubt creates an ethical dilemma intentionally diverting resources from the highest crime areas could be discriminatory, as it deprives minority communities of needed protection from the police (Mohler et al., 2018). Minority communities often request more police intervention (Kennedy, 1998), but again this 
needs to be weighed in relation to the potential unintended consequences that increased police presence in a community can entail. It is also not necessarily the case that targeting a very specific area or subset of individuals will deter the most crime. Since the police's effort is zerosum, disproportionately targeting one area could cause crime to increase in another area (Harcourt, 2007). ${ }^{1}$ Police departments will always need to make a decision of where to (and where not to) distribute their limited resources. It may be the public (or law enforcement agencies themselves) prefer to reduce racial disparity in police contacts even if it comes with some loss in efficiency of crime reduction initiatives (Cohen, 2017).

These ethical considerations show the potential trade-offs a police department faces when allocating proactive policing resources. Sending officers into a particular area and conducting stops and generating arrests may result in temporary crime reductions (Sherman, 1990), but has the potential to generate long term negative consequences among particular racial groups (Sharkey, 2018). This article attempts to show how one can incorporate such trade-offs into a hot spots policing algorithm, and quantify the loss in efficiency in targeting high crime places while trying to also limit the amount of DMC hot spots policing is likely to produce.

\section{Police Stops in New York City}

One of the original progenitors of the popularity of hot spots policing was the CompStat program (Weisburd et al., 2003), first implemented by the New York City Police Department (NYPD). What came along with CompStat was the tactic of broken windows policing (Kelling

\footnotetext{
${ }^{1}$ Note this argument is not saying that crime displacement occurs, that police shift an offender from committing a crime at location A to location B by conducting a hot spots policing initiative at A. Evidence of spatial displacement occurring from hot spots policing initiatives is quite weak overall (Bowers et al., 2011). What this is saying is that if hot spots policing reduces crime at all, then choosing to not implement hot spots policing at location B is by necessity failing to prevent some crimes that would not have occurred at location B had that location been targeted for a hot spots policing initiative.
} 
and Coles, 1997), which focused on targeting minor levels of disorder before they accumulated into more serious criminal behaviors (Kelling and Wilson, 1982).

Initially under Commissioner William Bratton, this took a form of an increase in lower level, misdemeanor arrests (Rosenfeld, Fornango, \& Rengifo, 2007), but later under Commissioner Raymond Kelly turned to focusing on stop, question, and frisk (Levitt, 2018). In addition to the routine CompStat meetings, during Kelly's tenure the NYPD had impact zones; hot spot areas of violent crime that were the specific target of additional police attention (MacDonald, Fagan, \& Geller, 2016; Smith \& Purtell, 2007).

The evidence of the crime reduction benefits of broken windows policing, as well as more specifically stop, question, and frisk, have been mixed (Greenberg, 2014; MacDonald, Fagan, \& Geller, 2016; Rosenfeld et al., 2007; Rosenfeld \& Fornango, 2017; Weisburd et al., 2016; Wooditch \& Weisburd, 2016). While New York City saw large crime reductions around the time CompStat was implemented, so too did many other cities in the United States, what is commonly referred to as the great crime decline (Blumstein \& Wallman, 2000).

But even if successful in reducing crime, the implementation of broken windows policing and stop, question, and frisk by the NYPD has been regularly criticized for disproportionately targeting minority communities (Fagan \& Davies, 2000; Gelman et al., 2007; Harcourt \& Ludwig, 2006). This criticism has taken two forms: one is the disproportionate number of stops and arrests of minorities within minority neighborhoods, even relative to the crime rate of those neighborhoods (Fagan \& Davies, 2000; Ferrandino, 2015; Gelman et al., 2007). The second form this criticism took was that the NYPD was indiscriminately stopping individuals without reasonable suspicion (Ferrandino, 2013; Geller \& Fagan, 2010; Goel, Rao, \& Shroff, 2016). Both of those factors resulted in civil litigation against the NYPD for $4^{\text {th }}$ and $14^{\text {th }}$ amendment 
violations (Fagan, 2017a), and resulted in a dramatic decline of the total number of stops, from over half a million per year in 2011 to currently under 20,000 per year (Ridgeway, 2017a).

More recent analyses of NYPD stop behavior have reported that police stops do not appear to be higher in minority neighborhoods when controlling for the reported number of crimes (MacDonald \& Braga, 2018), although other analyses have shown significant spatial heterogeneity in the ratio of stops to violent crime after the dramatic reduction in stops by the NYPD (Wheeler, Steenbeek, \& Andresen, 2018). Despite the absolute reduction in the total number of stops though, the proportion of stops of minority individuals by the NYPD have remained consistently high. The upper panel in Figure 1 displays the total number of reported stops by the NYPD from 2006 through 2017. The lower panel displays the total proportion of stops of minority individuals. ${ }^{2}$ Although the total number of stops have been greatly reduced starting in 2012, the proportion of stops of minorities is still very high, and has only fluctuated between $92 \%$ and $88 \%$, with the most recent years rising. This is much higher than the number of minority residents in New York City, 67\% Hispanic or non-white (MacDonald \& Braga, 2018).

Again, even if a police department is simply following the data and allocating resources to where crime was previously the highest, this can still create a system which increases DMC. The current data in New York City illustrate this - although the NYPD are not disproportionately targeting minority neighborhoods conditional on the neighborhoods reported crime in the most recent years (MacDonald \& Braga, 2018), it is still resulting in a large disparity in the proportion of minorities stopped relative to white individuals. The following section describes a potential

\footnotetext{
${ }^{2}$ Minority includes all stops in which the subject is not listed as white, including unknown or missing. From 2006 through 2016 the proportion unknown was always below 1\%. In 2017 it was $2.3 \%$.
} 
algorithmic solution to reduce this type of racial disparity in stops, while still targeting areas that have higher levels of crime.

[INSERT FIGURE 1 HERE]

\section{Linear Programming to Allocate Resources While Constraining Racial Inequality}

In the majority of hot spots policing algorithms, one would predict an area with the highest level of risk and allocate additional resources to that highest crime area, or similarly to a limited set of particular high crime places. This hot spots policing strategy works the same way if it is a forecast of future risk based on a regression equation (Caplan, Kennedy, \& Miller, 2011; Mohler et al., 2015), or based on simpler procedures, such as counting up the number of crimes that occurred in a particular area in the past few years and ranking them (Macbeth \& Ariel, 2017). One could additionally use weighted crime counts, such as harm indices (Ratcliffe, 2014).

\section{[INSERT TABLE 1 HERE]}

To articulate this hot spots policing strategy into a formula as to how police might distribute resources, I use three hypothetical areas (of the same size), their predicted crimes, and the percent minority within each area, which are shown in Table 1. A simple model of targeting hot spots of crime given these statistics may thus be:

$$
\operatorname{Maximize}\left\{x_{A}(60)+x_{B}(20)+x_{C}(3)\right\}
$$


Where the $x$ 's are the decision variables for whether to allocate resources to areas A, B, and C, and the police are maximizing the resources allocated to areas of high crime. The numbers within the parentheses correspond to the predicted number of crimes within each area.

Because police resources are finite, there are constraints on the total number of resources a police department can allocate to any particular area. For example, a department may just have a set of four officers whose duty it is to target recently identified hot spots of crime. In that case, the decision variables would have to sum to four, and would need to be integer values to appropriately allocate individual officers. Another way may be a department is deciding how to allocate all patrol resources. A simple way then to specify the system is to have a constraint that all of the decision variables are positive and sum to one, in which case you can interpret the decision variables as representing proportions of the total resources that should be allocated to each area. These types of linear programs are often referred to as mixing problems, and are typically solved using the simplex method (Hillier \& Liberman, 2005).

With no other constraints on the system besides the total number of resources to divvy up, this particular equation will always assign all of the resources to the single area with the most crime. That is, assigning $100 \%$ of your resources to area A will always maximize this equation. With the constraint that $x_{A}+x_{B}+x_{C}=1$, to maximize equation 1 one would set $x_{A}$ equal to 1 , and $x_{B}$ and $x_{C}$ equal to 0 .

There are often other constraints a police department may consider though when allocating resources, especially for a more general allocation strategy for all patrols instead of just one specialized unit. One obvious constraint is to have a minimum number of resources devoted to each area, so no area has zero police resources allocated. For example, for each $x$ one could place a minimum value constraint of 0.05 , which means no area can have fewer resources 
allocated than $5 \%$ of the total. An additional constraint one might have is a maximum allocation to any particular area - having $100 \%$ of resources devoted to one area would make police quite predictable (Ariel \& Partridge, 2017; Harcourt, 2007). An example could be an area can have no larger than $80 \%$ of the total resources allocated.

Besides constraints on the values the decision variables can take, one can place additional constraints on the solution returned based on additional information associated with the areas. The main motivation of this research is to introduce constraints on the expected number of minorities that are likely to come into contact with the police. Setting the constraint to a lower value will result in fewer minority contacts with the police, but come at a cost of allocating resources to areas that are not the highest crime. ${ }^{3}$

For instance, say one wanted to constrain the total number of minorities likely to be stopped by the police to $50 \%$ or less. Under our percentage resources in each area model, we would then specify the constraint:

$$
x_{A}(0.8)+x_{B}(0.5)+x_{C}(0.1) \leq 0.5
$$

Where the values within parentheses correspond to the proportion minority in each area. Given this constraint, one cannot devote $100 \%$ of the resources to area $\mathrm{A}$, as it would result in over $50 \%$ of the stops being of minorities, thus violating the constraint. One needs to shift some of the resources to area $\mathrm{B}$ or $\mathrm{C}$ to meet this racial equity constraint.

One strategy may be to allocate all of the police resources to area B, as that area has the highest predicted number of crimes, but still meets the 50\% minority constraint, which would

\footnotetext{
${ }^{3}$ Mohler et al. (2018) present a different way to accomplish a similar goal by creating a penalty factor in the selfexciting model that results in chosen hot spots being equal to the residential population.
} 
result in an objective function result of $1 \cdot 20=20$. But if we are attempting to maximize the number of resources at high crime places and still meet that expected minority stop constraint, it happens to be the best solution is to allocate $57.1 \%$ of the resources to area A, and $42.9 \%$ of the resources to area $\mathrm{C}$, for an objective function result of $0.571 \cdot(60)+0.429 \cdot(3)=35.6$. These particular values still meet the constraint of an expected proportion of minorities under $50 \%$ to come into contact with the police, $0.571 \cdot(0.8)+0.429 \cdot(0.1) \leq 0.5$. So in this case to meet our constraint we are better off allocating as many resources as possible to area A, while maintaining the minority constraint by devoting the necessary resources to area $\mathrm{C}$.

In more complicated situations it will not be just a choice between two areas, but many. In the case there was another area that had only $10 \%$ minority population, but had a higher level of crime, the algorithm would have chosen that area to balance out with area A, as opposed to area $\mathrm{C}$. Thus this algorithm combines either a hot spots or predictive policing algorithm, but does not equivocally say to allocate resources to the highest crime areas. With the race constraints it will never have a higher maximum objective value than a strategy with no race constraints, but is a quantitative way to get the best hot spots allocation strategy, while also limiting the amount of DMC to a set threshold.

Given that setting the constraint on the allowable minority contact will always be arbitrary, one can evaluate the trade-off in efficiency by setting more-or-less strict levels of racial equity, where efficiency is defined as the relative number of crimes a fixed number of hot spots capture in the racially constrained solution versus the unconstrained solution. For example, while setting the minority constraint to $50 \%$ results in an objective function value of 35.6 in this example, setting the minority constraint to $75 \%$ results in an objective function of 55.9 . Compared to the unconstrained solution of 60 , the $75 \%$ minority constraint is $93 \%$ efficient 
(55.9/60), and the $50 \%$ minority constraint is $59 \%$ efficient (35.6/60). It may be that one can reduce a sizeable amount of DMC with only a small loss in efficiency. But it may also be the case to achieve perfect equity relative to the resident population would incur dramatic losses in efficiency of targeting the highest crime places. Going back to the original hypothetical example in the introduction, trading off a location of 30 vs 28 robberies seems minor, but if the choice were between 30 vs 3 the trade-off is not as reasonable. The following analysis illustrates this trade-off in a realistic application using data on pedestrian stops and crimes in New York City.

\section{Data and Methods}

All of the data used in this analysis is publicly available. Data on the locations of stop, question, and frisk (SQF) were obtained from the NYPD at https://www1.nyc.gov/site/nypd/stats/reports-analysis/stopfrisk.page. Data on crime locations were obtained from https://opendata.cityofnewyork.us/. While data on SQF's were available going back to 2003 , the publicly available address geocoded crime information were only available going back to 2006. So this analysis focuses on SQF's and reported violent crime from 2006 through 2017. Part 1 violent crimes include murder, robbery, and aggravated assault (rapes are not disseminated in the publicly released crime data). Only considering stops and violent crimes with a valid geocoded coordinate, there were a total of $4,078,814$ pedestrian stops, and 446,448 Part 1 violent crimes over the 12 year period. ${ }^{4}$

The SQF and crime data are then aggregated to grid cells of 500 by 500 meters, which are nested within 77 precincts (based on the precinct the majority of the grid cell is located within).

\footnotetext{
${ }^{4}$ I additionally eliminate crimes reported at Riker's Island (the main jail complex for all of New York City) for this analysis, as that area would not be included in a hot spots policing strategy. There were no pedestrian stops reported on Riker's Island.
} 
Precincts were obtained from the Bytes of the Big Apple nyc.gov website, https://www1.nyc.gov/site/planning/data-maps/open-data/bytes-archive.page. Those grid cells are the areas in which the algorithm will differentially allocate police resources.

Grid cells are chosen over smaller street segments (Weisburd, Telep, \& Lawton, 2014), or census divisions such as blocks (MacDonald, Fagan, \& Geller, 2016), for several reasons. One is that stops tend to be recorded at the nearest intersection (Wooditch \& Weisburd, 2016), making it difficult to aggregate stops to either street segments or census divisions. The second is that estimates of the expected proportion of minorities stopped are taken directly from prior observed stops. So small areas such as street segments with few overall stops will have a large error in the estimated number of minorities that are likely to be stopped. Aggregating stops up to 500 by 500 meter grid cells partially avoids this problem. The hot spots allocation algorithm however is not particular to the spatial unit of analysis - it could as easily be applied to street segments or small grid cells.

Finally, since this is intended to be a hot spots policing allocation strategy, grid cells with fewer than 432 Part 1 violent crimes were eliminated. This number is chosen because it represents at least three Part 1 violent crimes per month in a grid cell over the twelve year study period (i.e. $3 * 12 * 12$ ). This results in a total of 327 grid cells meeting this criteria across New York City. The selection is ad-hoc (e.g. one could select areas with 1 or more violent crimes per month, or 300 violent crimes over the study period, etc.), but will ultimately only decrease the relative efficiency of the different hot spots policing solutions, as it effectively forces the decision variables for grid cells with fewer crimes than the cut-off selection to be zero. In discussing the results I will describe in more detail the effects that this cut-off has on the resulting efficiency estimates. In short, as this is intended to address a hot spots policing strategy, 
in makes little sense to target areas with very few crimes, and so only places that could

reasonably be considered hot spots of crime are included.

Instead of using the proportion of minorities previously stopped, one might use census estimates of the racial distribution for any particular place. Even when using grid cells one could do some type of areal allocation to estimate the proportion of the minority residential population (Kim, 2018). But this analysis uses the observed racial distribution of stops, as prior work has found that the available population to be stopped can be quite different than the residential population (Miller, le Masurier, \& Wicks, 2000; Waddington, Stenson, \& Don, 2004). ${ }^{5}$ Given the large number of prior stops in New York City, there is sufficient data to obtain accurate estimates of the proportion of minorities likely to be stopped in grid cells across the city.

One could similarly use the expected proportion of minorities arrested in place of the expected proportion of minorities stopped. Here we use overall stops, as stops themselves have been linked to negative outcomes (Brayne, 2014). In practice though the two strategies produce very similar results, as the arrest rate per stop between whites and minorities only varies slightly over New York City (Coviello \& Persico, 2015). The correlation between the proportion of minority stops and the proportion of minority arrests in this sample is $0.93 .^{6}$

\footnotetext{
${ }^{5}$ Using the 2014 five year American Community Survey estimates, I used proportional areal allocation to estimate the residential minority population within grid cells. While this estimate did have a high correlation of 0.81 with the estimated minority stop rate, the estimated minority stop rate was higher in the grid cell than the residential estimate in over $75 \%$ of the grid cells with at least one stop and one violent crime. This suggests if one were to use the residential census to construct the racial constraints, the actual minority stop rate would likely be higher than the racial constraints would suggest.

${ }^{6}$ Another approach that the algorithm might take is to try to maximize areas that result in higher arrest hit rates. We do not undertake that analysis here for two reasons. One, the arrest rates and the total number of stops appear to be inversely related, and so targeting areas of high hit rates results in choosing low crime areas. Two, arrest rates have gone dramatically up with the recent decrease in total number of stops in the NYPD data. This suggests that influencing the threshold of when officers decide to stop individuals is likely to be more fruitful for improving hit rates while still targeting hot spots (Goel et al., 2016).
} 
The estimate of the proportion of minorities likely to be stopped in a particular grid cell is calculated via a multi-level logistic regression model, nesting grid cell $i$ within precinct $j$ (Gelman \& Hill, 2007).

$$
\operatorname{Prob}\left(\text { Minority }_{i j}\right)=\operatorname{logistic}\left(\beta_{0}+\eta_{i}+\gamma_{j}\right)
$$

The $\eta$ term is a random intercept for each grid cell, the $\gamma$ term is a random intercept for each precinct, and $\beta_{0}$ is the global intercept. This equation provides the benefit of shrinkage compared to just using the observed minority stop rate. So for example, a location may have two out of four stops minorities (50\%), but the percent of minorities stopped across the precinct is closer to $40 \%$. The predicted proportion of minorities likely to be stopped in that grid cell in the future should then be somewhere between $50 \%$ and $40 \%$. Grid cells with fewer stops will then be shrunk more towards the precinct wide average. So nesting grid cells within precincts provides for some spatial smoothing, although other methods could reasonably be used as well (e.g. Savitz \& Raudenbush, 2009; Weisburd et al., 2014). If one wishes to use very small spatial units (often typical of predictive policing outputs), it will become more important to incorporate shrinkage and spatial smoothing into the estimates, as many of the small areas will have few stops, and so will have larger errors in the predicted number of minorities likely to come into contact with the police. For grid cells with zero stops the probabilities were imputed using the overall precinct wide probability.

For the spatial allocation strategy with racial equity constraints, resources are allocated to particular grid cells according to the function: 


$$
\operatorname{Maximize}\left\{\sum_{i}^{n} x_{i j} \cdot V_{i j}\right\}
$$

Subject to the constraints:

1. $\sum_{i}^{n} x_{i j}=1$

2. $0 \leq x_{i j} \leq 0.05$

3. $\sum_{i}^{n} M_{i j} \cdot x_{i j} \leq C$

Table 2 displays the definitions for each of the symbols used in the linear program.

Constraints 1 and 2 force the decision variables over all $n$ grid cells to sum to 1 , and are positive and between the values of 0 and 0.05 . Thus the decision variables can be interpreted as proportions of resources allocated to particular grid cells, but no grid cell can be allocated more than $5 \%$ of the total resources. What this means is that the procedure needs to at a minimum include a total of 20 locations to meet the constraints, but can include more if an area is allocated less than $5 \%$ of the total resources.

This tends to produce all or nothing results (that is an area is assigned $0 \%$ or $5 \%$ ), and so setting the upper limit on the resources allocated at $5 \%$ is similar to selecting 20 hot spot areas. If one wishes to have a strategy of a location is targeted or not, as opposed to a proportion allocation, the linear program can be amended to have the decision variables be explicitly binary (i.e. an integer linear program), which I show in Appendix A choosing 10 areas with qualitatively similar results to that described in the manuscript. 
Constraint 3 is the one applicable to reducing DMC. This constraint says that given the allocated resources to each grid cell, the total number of the expected minority contacts needs to be less than $C$. Given that $C$ is arbitrary, the analysis demonstrates the loss in efficiency when constraining $C$ to vary between $100 \%$ stops of minorities (no constraint) to $80 \%$ stops of minorities in increments of $1 \%$. While $67 \%$ of the resident population within New York City are minorities (MacDonald \& Braga, 2018), given the criteria of targeting this high of crime locations, obtaining a minority stop proportion smaller than $80 \%$ is not possible. For many different combinations of parameters solutions of fewer than $80 \%$ minority stops are not within the feasible solution, which the reason why this is the case will become clear when describing the results. This analysis focuses on just minority stops for simplicity in presentation, although one can set multiple constraints for individual racial and ethnic groups in the same way.

Since the resulting optimized number of crimes targeted has no intuitive explanation, I divide the resulting optimized value on the violent crime scale under varying levels of racial equity constraints by the optimized value when no minority constraints are in place. Thus the results can be interpreted as a relative loss in efficiency when constraining racial equity.

The objective function based on violent crimes is used for illustrative purposes of the technique. Again a police department may wish to use different priorities, such as targeting areas of forecasted high crime or using a weighted metric of crime harm instead of just violent crimes. These different priorities can easily be incorporated into the linear program by simply replacing $V_{i j}$ with whatever metric a department prefers. $^{7}$

The linear programming models were optimized using the python PuLP library (Mitchell, O’Sullivan, \& Dunning, 2011), using the CPLEX solver. Such linear programs can be estimated

\footnotetext{
${ }^{7}$ It is also possible to incorporate adjusted crime reporting rates for over- or under-reporting among particular demographic groups when choosing the targeted hot spots in this algorithm (Ensign et al., 2018).
} 
for many areas in a very short amount of time, so dynamic solutions updated in near real time are feasible for police departments (Leigh, Dunnett, \& Jackson, 2017).

\section{Analysis}

Figure 2 displays the relative loss in efficiency when constraining the algorithm to have more strict racial equity constraints, ranging from 100\% stops of minorities are acceptable (so no constraint) incrementally until the constraints need stops to be of less than or equal to $80 \%$ minority stops. As one can see, there is no loss in efficiency until there is a constraint that $96 \%$ or fewer of the stops should be of minorities. Then the curve slopes downward, with under $90 \%$ efficiency for $90 \%$ minorities, but accelerates to only around $55 \%$ efficient for the more severe restriction of $80 \%$ stops of minorities. If one considers the total amount of resources devoted to a hot spot as a weight, the mean weighted number of crimes within a hot spot for the unconstrained model is 1,161 , whereas the model with the $80 \%$ minority constraint is 638 . Considering the data is over 12 years, this results in an average of 8 violent crimes per month in a targeted hot spot for the unconstrained model, and fewer than 5 violent crimes per month in the targeted hot spots under the more strict racial constraints.

For this set of parameters, $80 \%$ minority was the last feasible solution, a solution with $79 \%$ minority stops was not possible with this particular set of data. Why this is the case will likely become clear when viewing Figure 3, which shows that the majority of high crime places tend to result in a very large proportion of minorities stopped, with very few high crime places with fewer than $80 \%$ of stops of minorities.

[INSERT FIGURE 2 AND FIGURE 3 HERE] 
The left most panel in Figure 3 shows the resulting solution for the hot spots algorithm when there is no racial constraint (e.g. $100 \%$ of the stops could be of minorities). In this case, the algorithm reduces to simply selecting the 20 highest crime locations and giving each of those areas $5 \%$ of the total resources. All but one of those areas are in locations that have more than $95 \%$ stops of minorities. This blatantly shows that simply targeting the highest crime locations in a hot spots policing algorithm is likely to exacerbate DMC, even if those hot spots are objectively in the highest crime places.

The central panel in Figure 3 shows the hot spots allocation strategy with a 90\% minority constraint. As one can see, this swaps out places with fewer crimes, but have a lower proportion of minorities likely to be stopped. Subsequently the strategy tends to select areas that are along the diagonal of the scatterplot and are closer to the top left corner. So instead of unequivocally choosing the top 20 locations, this strategy selected a wider variety of hot spots. There ended up only being two locations that were not given the maximum amount of $5 \%$ of the resources, so this strategy targets 21 areas instead of the 20 in the prior no constraint solution.

The right most panel displays the solution with $80 \%$ or fewer minorities stopped constraint. This shows that every location with fewer than an expected $80 \%$ of minorities likely to be stopped is chosen, with only one of the highest crime grid cells chosen, and that only includes a partial allocation of less than $5 \%$ of the total. This shows why no solutions of fewer than $80 \%$ minorities stopped is feasible in this particular set of high crime grid cells - there are not enough locations of low proportion minority areas to target 20 different hot spots.

If one was targeting fewer hot spots than 20 , one could find feasible solutions within this set for minority stop constraints of fewer than $80 \%$. There are several outliers along this 
continuum that can be seen in the chart, but these areas are $85 \%$ or $79 \%$ minority relative to over 95\% minority. They still tend to be areas with a much higher proportion of minorities compared to the overall residential population in New York City.

When not restricting the sample space to grid cells with over 432 violent crimes, the allocation strategy showed less loss in efficiency, but tended to have much more severe tradeoffs in targeting high crime places. For example, a grid cell with only one violent crime over the twelve year period, but stops in that grid cell tended to be only $10 \%$ minority, was often chosen when including all grid cells with at least one crime. This is why the sample is restricted to only areas that are reasonably high crime, as an area with so few of crimes is not reasonable to target with a hot spots policing strategy. With such a low baseline police could never reasonably expect to deter future crimes in that location. But the restriction in this data set to only very high crime places comes at the cost of not being able to have racial constraints much lower than $80 \%$. It is the nature of the data that the highest crime places tend to also generate a much higher proportion of minority stops. There are essentially no high crime majority white areas in New York City. This fact is not the exception, but rather the rule for the majority of American cities (Sampson, 2012; Sampson \& Wilson, 1995). ${ }^{8}$

\section{Discussion}

Current hot spots policing tactics, as well as predictive policing, have a potential consequence of increasing DMC (Brayne, 2017; Fagan, 2017a; Kochel, 2011). To date suggestions by scholars that potentially limit the disparate outcomes among minority citizens in targeted hot spots of crime tend to focus on the type of policing that is undertaken. Examples

\footnotetext{
${ }^{8}$ I have placed spatial maps showing the distribution of hot spots chosen by the algorithm in Appendix B. In short, selecting more hot spots in lower Manhattan would reduce DMC, whereas the unconstrained solution tended to select hot spots in upper Manhattan and the Bronx.
} 
include focusing on problem oriented policing as opposed to more traditional policing tactics such as stops and arrests (Braga \& Apel, 2016; Braga et al., 1999; Owens et al., 2018), or improving perceptions of police legitimacy during police interactions with the public (Braga, Brunson, \& Drakulich, 2019; Lum \& Nagin, 2017; Owens et al., 2018). But problem oriented policing often devolves into more traditional policing (Braga \& Bond, 2008), and one should not entirely dismiss the capability of traditional approaches, such as conducting more police stops in hot spots of crime, to reduce crime (Groff et al., 2015; Rosenfeld, Deckard, \& Blackburn, 2014; Weisburd, Telep, \& Lawton, 2014). If proactive policing is going to be the mechanism through which criminologists champion to reduce crime (Durlauf \& Nagin, 2011; Nagin, Solow, \& Lum, 2015), we need to be aware of potential adverse impacts those strategies may have beyond any immediate positive benefits of crime reduction (Braga, 2016; Clear, 2008; Cohen, 2017; Tonry, 2011). Even if street stops are perceived as legitimate, they can have negative long term consequences for individuals (Brayne, 2014), may sustain current systematic inequalities faced by minorities (Brayne, 2017), and perpetuate neighborhoods of concentrated disadvantage (Fagan, West, \& Holland, 2002; Morenoff \& Harding, 2014). The police taking steps to ensure that place based policing strategies lessen disparate impact is itself an important step to generate public and organizational legitimacy (Worden \& McLean, 2017). In the long run, such increases in legitimacy should also promote more cooperation with the police (Braga, Brunson, \& Drakulich, 2019; Tyler, 2017).

While prior efforts to monitor the NYPD for disparate impact have shown reductions in racial disparities along some dimensions (MacDonald \& Braga, 2018), it did not reduce the overall proportion of minorities that tended to be stopped by police. So while police stops in New York City are fair along one particular criterion, there continues to be disparity in the 
proportion of minorities stopped relative to their share of the residential population by a wide margin. Around 90 percent of stops are of minorities, whereas they make up less than 70 percent of the residential population in New York City. Thus to reduce DMC, it will take a new approach beyond the previous benchmarking tools prior scholars have used to identify whether police stops are resulting in racial disparity.

Such a reduction will not come about by conforming to the current status-quo of hot spots or predictive policing methods, even if one can argue that such predictive models are fair or objective. Prior examples of limiting judge and prosecutorial discretion, although fair in terms of being applied equally no matter the color of one's skin, resulted in disparate impact towards minorities (Petit \& Western, 2004). Predictive policing algorithms have the same risk - if applied indiscriminately they may result in disparate impact towards particular vulnerable populations (Brayne, 2017).

The means through which such disparate impact would come about with predictive policing systems is through increasing contact with the police and subsequent arrests. This disparate impact is likely to continue even in the face of using objective measures of reported crime independent of prior police behavior, although increased detection of certain crimes will additionally exacerbate how predictive systems can be biased to prioritize areas that have historically been targeted by police (Ensign et al., 2018).

Those police contacts are likely to result in a larger proportion of minorities incarcerated and with criminal records (Goldkamp \& Vîlcicã, 2008), which may further instigate more crime in those previously high crime neighborhoods when large numbers of individuals in those communities are incarcerated (Fagan, West, \& Holland, 2002; Hannon \& Defina, 2012; Morenoff \& Harding, 2014). Also disparity in police arrests inevitably lead to disparity at later 
points in the criminal justice system, such as community supervision or incarceration, as police are the gatekeepers that introduce individuals into the criminal justice system. Interventions at later points in the criminal justice system cannot be expected to entirely reduce racial disparity introduced at the earlier arrest stage, so the onus needs be on police departments to reduce DMC if one wants to reduce the level of disparate impact across the criminal justice system.

The algorithm proposed here can be applied to reduce DMC, and provides an objective way to formulate the trade-off of targeting high crime places while also striving towards an additional goal of racial equity. This provides a transparent way that police departments can both target areas of historically high levels of crime, while also demonstrating to their community that they take the potential negative consequence of over-policing particular minority groups seriously. While such a strategy in the short term will not result in more crime reductions than would targeting the absolute highest crime locations, in the long run it has the potential to reduce adverse consequences of DMC. In particular, it should reduce the number of minorities stopped and arrested by police. But that reduction comes with a cost of not equivocally targeting the highest crime locations in a hot spots policing strategy (Mohler et al., 2018).

An importing finding in this work that is that it was not feasible to allocate resources to hot spots that brought about a proportion of minority police contact rate equal to the proportion minority residential population in New York City. This finding can be interpreted in several different ways. One is that the spatial allocation approach advocated here will never be able to solve DMC, and thus police departments will need to rely on other approaches to reduce the harms that come about via proactive strategies. While it is true that using different, non-stop or arrest diversion based strategies may reduce the impact of DMC, ultimately the spatial distribution of police has an impact on who is stopped and arrested. If a police department sends 
officers to a particular hot spot, even if they are intended to engage in community policing strategies, they will observe more crimes, stop more individuals, and make arrests based on those contacts. Even if some policing strategies mitigate (or exacerbate) the overall level of contact, the relative disparity brought about by spatially allocating police to different areas will still exist. The spatial allocation strategy suggested here should be used in conjunction with those other policing strategies intended to mitigate long term harm to particular communities.

Another, more positive interpretation is that smaller gains in reducing DMC can be had by this algorithm, even if reductions exactly equal to the residential population are not feasible. In particular, NYPD has not reduced the overall proportion of minority stops in recent years. If the NYPD wishes to move that needle to a lower than $90 \%$ minority stop rate, this algorithm provides a particular strategy to do so.

Beyond the NYPD, it seems the best use case scenario of this algorithm is in conjunction with current predictive policing technologies. It provides a way to still target hot spots, but provide assurances that the predictive policing approach will not exacerbate DMC, and can potentially reduce it compared to the status quo. The algorithm presented here provides a specific strategy to reduce DMC that can be used in conjunction with current predictive policing strategies. Obtaining perfect parity in the proportion of minorities stopped should not be the enemy of reducing some disparity if feasible, especially if it does not result in large reductions in efficiently targeting crime hot spots. In other jurisdictions after drawing the curve of the loss in efficiency relative to different racial constraints it may show a bend where the constraints result in more dramatic losses in efficiency, suggesting a natural place where one might set the racial constraint. 
This algorithm, of course, has limitations. First is that it cannot tell police what to do at hotspots of crime, it can only provide a formula to determine where police resources should be allocated. This is a current hard problem faced by all hot spots and predictive policing strategies (Weisburd \& Telep, 2014). Certain policing tactics, even if they bring about crime declines, can be perceived by the community as illegitimate. So any police strategy should be cognizant of behavior that produces negative perceptions among their constituents (Lum \& Nagin, 2017). The allocation algorithm proposed here is not mutually exclusive with other practices intended to mitigate the potential negative consequences of invasive policing, such as arrest diversionary programs or encouraging police to act procedurally just in their encounters with suspects.

A second limitation is that this work focuses on the relative distribution of resources, it does not address the total amount of resources that should be allocated to any particular location or to a hot spots policing tactic in general. This critique is also relevant in that trying to balance racial equity in terms of the total proportion of minorities stopped may not be the best way to prevent adverse consequences related to over-policing certain minority groups. It may be the case that the majority of negative externalities of increased police invasiveness come only through the absolute number of contacts with the police and arrests (Manski \& Nagin, 2017). In that case, whether there is relative racial balance is immaterial, but simply reducing the absolute number of minorities stopped and arrested will promote more positive long term outcomes in minority neighborhoods. If this is true, then the NYPD would likely have already reduced any disparate impact stops had in minority communities via the extreme overall reduction of pedestrian stops. It is also the case if true then it is immaterial whether a high proportion of stops are of minorities, or even whether stops tend to be in direct ratio with prior crime complaints (MacDonald \& Braga, 2018). It also is not the only aspect of disparity that a police department 
may choose to tackle. In particular in the NYPD complaints about the relatively low arrest rate is another critique besides disproportionately targeting minority areas, and there have been other proposed strategies to increase those hit rates based on predictive models (Goel et al., 2016).

However, the algorithm presented here is not only illustrative of the potential DMC generated via a hot spots policing strategy in New York City, but any. Given that questions of over-policing are quite regular, and often only addressed ex-ante in response to civil litigation (Tillyer, Engel, \& Wooldredge, 2008), this work provides an important step in making a proactive strategy consider additional costs in terms of DMC. An important step for future research though is to more precisely quantify the actual costs of DMC and over-policing. Some may consider any trade-off in reduced safety is unreasonable, no matter how small. Only in conjunction with actually admitting the potential harm that DMC can produce will not allocating resources to minority neighborhoods be reasonable. Given that such calls are currently being made (Fagan, 2017a, 2017b), this algorithm is an important contribution to achieve reductions in DMC with an actual strategy that police can follow, as opposed to simply ex-ante determining whether police stops are distributed equitably according to race (MacDonald \& Braga, 2018). Such calls will always be controversial though, unless the costs of over-policing can be more precisely estimated.

A third limitation is that this strategy cannot explicitly force racial equity in stops. Although the algorithm can say a particular location should be allocated a certain percentage of resources, even if an area is allocated more policing resources it will not necessarily result in more stops. If an area assigned fewer resources yields more reasonable suspicion pedestrian stops, and those locations tend to be higher minority, this strategy would not produce as much racial equity as would be expected via the model. All police should monitor the quality of stops 
and arrests, because if they are incentivized it is likely the case that officers will use lower standards to stop individuals (Fagan, 2017a). Such negative consequences could happen with this algorithm, the same as any hot spots policing strategy. Police should not go and stop more white suspects just to meet an external standard of racial equity, the same as they should not ignore criminal behavior by minorities that they observe to meet the same objective. The current distribution of police resources has a large impact on what criminal behaviors police do observe though, and so incorporating an allocation strategy that takes into account the expected number of minorities to be stopped is likely to reduce the amount of DMC created via police stops and arrests.

A fourth limitation is that this algorithm, nor any, can quantify the ethical trade-off in not targeting resources at particular locations. Police allocating extra resources for proactive or other approaches by necessity is a zero-sum proposition: allocating resources to one area means depriving another area of those same resources. This algorithm explicitly reduces police intervention at hot spots of crime that contain the highest proportion of minorities. This can be seen as unethically depriving minority communities of needed protection by the police. Only weighing this trade-off with the potential adverse consequences of DMC with the police can depriving specific communities of those resources be justified.

Here I provide some quantitative estimates of the loss in total efficiency of targeting high crime areas when considering alternative objectives of reducing the proportion of minorities stopped. But using other criterions of valuing crime and its harm, or conducting the analysis in a different jurisdiction, will result in different estimates of the loss in efficiency. However, there will always be some trade-off in targeting the highest crime places versus balancing racial equity, no matter where or how that trade-off is estimated. Future research may evaluate whether 
law enforcement or the general public would be willing to except such trade-offs (Carson \& Louviere, 2017). This algorithm provides precise quantitative estimates to evaluate those tradeoffs, and so can be used in surveys on evaluating subjective perceptions of whether individuals feel that trade-off is ethically justifiable. Ultimately the racial constraints provided are arbitrary, and allowing different groups decide where they ultimately want to set the racial constraint is a strength of the algorithm proposed here. The fact setting the racial constraint is in part an ethical question does not mean one should ignore quantitative evidence in helping to guide that decision.

Current critiques of predictive algorithms often state they ignore how historical processes shape the current data that is fed into the system, and as such likely perpetuate the current statusquo (Harcourt, 2007; Lum \& Isaac, 2016). Predictive algorithms are not limited to a simple objective of improving forecast accuracy though - they can be amended to take into account additional objectives (Hardt, Price, \& Srebro, 2016; Mohler et al., 2018). As opposed to saying predictive algorithms will hopelessly exacerbate racial disparities already prevalent in the criminal justice system, this is but one example of how they can be amended to attempt to reduce racial disparity. While predictive algorithms applied blindly no doubt have the potential to cause harm, whether in the criminal justice system or in other aspects of our lives, they can also be used for good. The criminal justice community simply needs to articulate fair and efficient outcomes to strive for.

\section{References}

Angwin, J., Larson, J., Mattu, S., \& Kirchner, L. (2016). Machine bias: There's software used across the country to predict future criminals. And it's biased against blacks. ProPublica, https://www.propublica.org/article/machine-bias-risk-assessments-in-criminalsentencing. Last obtained on 3/29/2018.

Ariel, B., \& Partridge, H. (2017). Predictable policing: Measuring the crime control benefits of hotspots policing at bus stops. Journal of Quantitative Criminology 33, 809-833. 
Barbe, P., \& Horrace, W.C. (2012). A critical reanalysis of Maryland State Police searches. The American Statistician 66, 1-7.

Baumer, E.P. (2002). Neighborhood disadvantage and police notification by victims of violence. Criminology 40, 579-616.

Berk, R.A. (2016). A primer on fairness in criminal justice risk assessments. The Criminologist 41, 6-9.

Blumstein, A., \& Wallman, J. (2000). The crime drop in America. Cambridge, UK: Cambridge University Press.

Bowers, K.J., Johnson, S.D., Guerette, R.T., Summers, L., \& Poynton, S. (2011). Spatial displacement and diffusion of benefits among geographically focused policing initiatives: A meta-analytical review. Journal of Experimental Criminology 7, 347-374.

Braga, A.A. (2016). The continued importance of measuring potentially harmful impacts of crime prevention programs: The academy of experimental criminology 2014 Joan McCord lecture. Journal of Experimental Criminology 12, 1-20.

Braga, A.A., \& Apel, R. (2016). And we wonder why criminology is sometimes considered irrelevant in real-world policy conversations. Criminology \& Public Policy 15, 813-829.

Braga, A.A., \& Bond, B.J. (2008). Policing crime and disorder hot spots: A randomized controlled trial. Criminology 46, 577-607.

Braga, A.A., Brunson, R.K., \& Drakulich, K.M. (2019). Race, place, and effective policing. Annual Review of Sociology 45.

Braga, A.A., Papachristos, A.V., \& Hureau, D.M. (2014). The effects of hot spots policing on crime: An updated systematic review and meta-analysis. Justice Quarterly 31, 633-663.

Braga, A.A., Weisburd, D.L., Waring, E.J., Mazerolle, L.G., Spelman, W., \& Gajewski, F. (1999). Problem-oriented policing in violent crime places: A randomized controlled experiment. Criminology 37, 541-580.

Brantingham, P.J., Valasik, M., \& Mohler, G.O. (2018). Does predictive policing lead to biased arrests? Results from a randomized controlled trial. Statistics and Public Policy 5, 1-6.

Brayne, S. (2014). Surveillance and system avoidance: Criminal justice contact and institutional attachment. American Sociological Review 79, 367-391. 
Brayne, S. (2017). Big data surveillance: The case of policing. American Sociological Review 82, 977-1008.

Caplan, J.M., Kennedy, L.W., \& Miller, J. (2011). Risk terrain modeling: Brokering criminological theory and GIS methods for crime forecasting. Justice Quarterly 28, 360381.

Carson, R.T., \& Louviere, J.J. (2017). Estimation of broad-scale tradeoffs in community policing policies. Journal of Benefit-Cost Analysis 8, 385-398.

Clear, T.R. (2008). The effects of high imprisonment rates on communities. Crime and Justice 37, 97-132.

Cohen, M.A. (2017). The social cost of a racially targeted police encounter. Journal of BenefitCost Analysis 8, 369-384.

Corbett-Davies, S., Pierson, E., Feller, A., Goel, S., \& Huq, A. (2017). Algorithmic decision making and the cost of fairness. KDD August, 797-806.

Coviello, D., \& Persico, N. (2015). An economic analysis of black-white disparities in the New York Police Department's Stop-And-Frisk program. Journal of Legal Studies 44, 315 360.

Durlauf, S.N., \& Nagin, D.S. (2011). Imprisonment and crime. Criminology \& Public Policy 10, 13-54.

Eckhouse, L., Lum, K. Conti-Cook, C., \& Ciccolini, J. (2019). A unified approach for understanding problems with risk assessment. Criminal Justice and Behavior 46, 185 209.

Engel, R.S., \& Tillyer, R. (2008). Searching for equilibrium. Justice Quarterly 25, 54-71.

Ensign, D., Friedler, S.A., Neville, S., Scheidegger, \& Venkatasubramanian, S. (2018). Runaway feedback loops in predictive policing. Proceedings of Machine Learning Research. Conference on Fairness, Accountability, and Transparency 81,1-12. Available at http://proceedings.mlr.press/v81/ensign18a/ensign18a.pdf.

Fagan, J. (2017a). Recent evidence and controversies in "The New Policing”. Journal of Policy Analysis and Management 36, 690-700.

Fagan, J. (2017b). Response to Ridgeway: Allocating police. Journal of Policy Analysis and Management 36, 703-707. 
Fagan, J, \& Davies, G. (2000). Street stops and broken windows: Terry, race, and disorder in New York City. Fordham Urban Law Journal 28, 457-504.

Fagan, J., West, V., \& Holland, J. (2002). Reciprocal effects of crime and incarceration in New York City neighborhoods. Fordham Urban Law Journal 30, 1551-1599.

Ferrandino, J. (2013). The efficiency of frisks in the NYPD, 2004-2010. Criminal Justice Review $38,149-168$.

Ferrandino, J. (2015). Minority threat hypothesis and NYPD stop and frisk policy. Criminal Justice Review 40, 209-229.

Geller, A., \& Fagan, J. (2010). Pot as pretext: Marijuana, race, and the new disorder in New York City street policing. Journal of Empirical Legal Studies 7, 591-633.

Gelman, A., Fagan, J., \& Kiss, A. (2007). An analysis of the New York City Police Departments "Stop-and-Frisk" policy in the context of claims of racial bias. Journal of the American Statistical Association 102, 813-823.

Gelman, A., \& Hill, J. (2007). Data analysis using regression and multilevel/hierarchical models. New York, NY: Cambridge University Press.

Goel, S., Rao, J.M., \& Shroff, R. (2016). Precinct or prejudice? Understanding racial disparities in New York City's stop-and-frisk policy. The Annals of Applied Statistics 10, 365-394.

Goldkamp, J.S., \& Vîlcicã, E.R. (2008). Targeted enforcement and adverse system side effects: The generation of fugitives in Philadelphia. Criminology 46, 371-409.

Greenberg, D.F. (2014). Studying New York City's crime decline: Methodological issues. Justice Quarterly 31, 154-188.

Groff, E.R., Ratcliffe, J.H., Haberman, C.P., Sorg, E.T., Joyce, N.M., \& Taylor, R.B. (2015). Does what police do at hot spots matter? The Philadelphia policing tactics experiment. Criminology 53, 23-53.

Grogger, J., \& Ridgeway, G. (2006). Testing for racial profiling in traffic stops from behind a veil of darkness. Journal of the American Statistical Association 101, 878-887.

Hannon, L., \& DeFina, R. (2012). Sowing the seeds: How adult incarceration promotes juvenile delinquency. Crime, Law and Social Change 57, 475-491.

Harcourt, B.E. (2007). Against prediction: Profiling, policing, and punishing in an actuarial age. Chicago, IL: The University of Chicago Press. 
Harcourt, B.E., \& Ludwig, J. (2006). Broken windows: New evidence from New York City and a five-city social experiment. The University of Chicago Law Review 73, 271-320.

Hardt, M., Price, E., \& Srebro, N. (2016). Equality of opportunity in supervised learning. Advances in Neural Information Processing Systems 29, 3315-3323.

Hillier, F.S., \& Liberman, G.J. (2005). Introduction to operations research. Boston, MA: McGraw Hill Higher Education.

Kelling, G.L., \& Coles, C.M. (1997). Fixing broken windows: Restoring order and reducing crime in our communities. The Free Press: New York, NY.

Kelling, G.L., \& Wilson, J.Q. (1982). The police and neighborhood safety: Broken windows. The Atlantic 127, 29-38.

Kennedy, D.M. (1996). Pulling levers: Chronic offenders, high-crime settings, and a theory of prevention. Valparaiso University Law Review 31, 449-484.

Kennedy, R. (1998). Race, crime, and the law. New York, NY: Random House.

Kim, Y.A. (2018). Examining the relationship between the structural characteristics of place and crime by imputing census block data in street segments: Is the pain worth the gain? Journal of Quantitative Criminology 34, 67-110.

Kleinberg, J., Ludwig, J., Mullainathan, S., \& Rambachan, A. (2018). Algorithmic fairness. American Economic Association Papers and Proceedings 108, 22-27.

Kochel, T.R. (2011). Constructing hot spots policing: Unexamined consequences for disadvantaged populations and for police legitimacy. Criminal Justice Policy Review 22, 350-374.

Leigh, J., Dunnett, S., \& Jackson, L. (2017). Predictive police patrolling to target hotspots and cover response demand. Annals of Operations Research, Online First.

Lerman, A.E., \& Weaver, V. (2014). Staying out of sight? Concentrated policing and local political action. The ANNALS of the American Academy of Political and Social Science $651,202-219$.

Levitt, L. (2018). The mysteries of crime. NYPD Confidential: An Inside Look at the New York Police Department. Available at http://nypdconfidential.com/columns/2018/180101.html.

Lum, C., Nagin, D.S. (2017). Reinventing American policing. Crime and Justice 46, 339-393. 
Lum, K., \& Isaac, W. (2016). To predict and serve? Significance 13, 14-19.

Loeffler, C., \& Flaxman, S. (2018). Is gun violence contagious? A spatiotemporal test. Journal of Quantitative Criminology 34, 999-1017.

Macbeth, E., \& Ariel, B. (2017). Place-based statistical versus clinical predictions of crime hot spots and harm locations in northern Ireland. Justice Quarterly Online First.

MacDonald, J., \& Braga, A.A. (2018). Did post-Floyd et al. reforms reduce racial disparities in NYPD stop, question, and frisk practices? An exploratory analysis using external and internal benchmarks. Justice Quarterly Online First.

MacDonald, J, Fagan, J, \& Geller, A. (2016). The effects of local police surges on crime and arrests in New York City. PLOS ONE 11, e0157223.

Manski, C.F., \& Nagin, D.S. (2017). Assessing benefits, costs, and disparate racial impacts of confrontational proactive policing. Proceedings of the National Academy of Sciences 114, 9308-9313.

Miller, J., le Masurier, P., \& Wicks, J. (2000). Profiling populations available for stops and searches. Police Research Series, Home Office.

Mohler, G.O., Raje, R., Valasik, M., Carter, J., \& Brantingham, P.J. (2018). A penalized likelihood method for balancing accuracy and fairness in predictive policing. IEEE International Conference on Systems, Man, and Cybernetics. Available at https://www.researchgate.net/profile/Jeremy_Carter2/publication/327057079_A_penalize d likelihood_method_for_balancing accuracy and fairness in predictive policing/links 15b75769745851546c909dacc/A-penalized-likelihood-method-for-balancing-accuracyand-fairness-in-predictive-policing.pdf.

Mohler, G.O., Short, M.B., Malinowski, S., Johnson, M., Tita, G.E., Bertozzi, A.L., \& Brantingham, P.J. (2015). Randomized controlled field trials of predictive policing. Journal of the American Statistical Association 110, 1399-1411.

Mitchell, S., O’Sullivan, M., \& Dunning, I. (2011). PuLP: A linear programming toolkit for python. Available at http://www.optimization-online.org/DB FILE/2011/09/3178.pdf.

Morenoff, J.D., \& Harding, D.J. (2014). Incarceration, prisoner reentry, and communities. Annual Review of Sociology 40, 411-429.

Nagin, D.S., Solow, R.M., \& Lum, C. (2015). Deterrence, criminal opportunities, and police. Criminology 53, 74-100. 
Nagin, D.S., \& Telep, C.W. (2017). Procedural justice and legal compliance. Annual Review of Law and Social Science 13, 5-28.

Owens, E., Weisburd, D., Amendola, K.L., \& Alpert, G.P. (2018). Can you build a better cop? Experimental evidence on supervision, training, and policing in the community. Criminology \& Public Policy 17, 41-87.

Pager, D. (2003). The mark of a criminal record. American Journal of Sociology 108, 937-975.

Petit, B., \& Western, B. (2004). Mass imprisonment and the life course: Race and class inequality in U.S. incarceration. American Sociological Review 69, 151-169.

Pickett, J.T., \& Roche, S.P. (2016). Arrested development: Misguided directions in deterrence theory and policy. Criminology \& Public Policy 15, 727-751.

Ratcliffe, J.H. (2014). Towards an index for harm-focused policing. Policing: A Journal of Policy and Practice 9, 164-182.

Ratcliffe, J.H., Groff, E.R., Sorg, E.T., \& Haberman, C.P. (2015). Citizens' reactions to hot spots policing: Impacts of perceptions on crime, disorder, safety and police. Journal of Experimental Criminology 11,393-417.

Ridgeway, G. (2017a). Stop-and-frisk is essential... and requires restraint. Journal of Policy Analysis and Management 36, 683-689.

Ridgeway, G. (2017b). Response to Fagan. Journal of Policy Analysis and Management 36, 700703.

Ridgeway, G., \& MacDonald, J.M. (2009). Doubly robust internal benchmarking and false discovery rates for detecting racial bias in police stops. Journal of the American Statistical Association 104, 661-668.

Rosenfeld, R., Deckard, M.J., \& Blackburd, E. (2014). The effects of directed patrol and selfinitiated enforcement on firearm violence: A randomized controlled study of hot spot policing. Criminology 52, 428-449.

Rosenfeld, R., Fornango, R., \& Rengifo, A.F. (2007). The impact of order-maintenance policing on New York City homicide and robbery rates: 1988-2001. Criminology 45, 355-384.

Rosenfeld, R., \& Fornango, R. (2017). The relationship between crime and stop, question, and frisk rates in New York City neighborhoods. Justice Quarterly, 34, 931-951. 
Sampson, R.J. (2012). Great American City: Chicago and the enduring neighborhood effect. Chicago, IL: University of Chicago Press.

Sampson, R.J., \& Raudenbush, S.W. (2004). Seeing disorder: Neighborhood stigma and the social construction of "Broken Windows”. Social Psychology Quarterly 67, 319-342.

Sampson, R.J., \& Wilson, W.J. (1995). Toward a theory of race, crime, and urban inequality. In Hagan, J., \& Peterson, R.D. (eds.). Crime and Inequality. California: Stanford University Press.

Saunders, J., Hunt, P., \& Hollywood, J.S. (2016). Predictions put into practice: A quasiexperimental evaluation of Chicago's predictive policing pilot. Journal of Experimental Criminology 12, 347-371.

Savitz, N.V., \& Raudenbush, S.W. (2009). Exploiting spatial dependence to improve measurement of neighborhood social processes. Sociological Methodology 39, 151-183.

Sharkey, P. (2018). Uneasy Peace: The Great Crime Decline, The Renewal of City Life, and the Next War on Violence. New York, NY: W.W. Norton \& Company.

Shaw, C.R., \& McKay, H.D. (1969). Juvenile delinquency and urban areas: A study of rates of delinquency in relation to differential characteristics of local communities in American Cities. Revised Edition. Chicago, IL: University of Chicago Press.

Sherman, L.W. (1990). Police crackdowns: Initial and residual deterrence. Crime and Justice 12, $1-48$.

Smith, D.C., \& Purtell, R. (2007). An empirical assessment of NYPD's “Operation Impact”: A targeted zone crime reduction strategy. NYU Wagner Graduate School of Public Service Paper. Available at https://wagner.nyu.edu/node/1396.

Stemen, D. \& Rengifo, A.F. (2011). Policies and imprisonment: The impact of structured sentencing and determinate sentencing on state incarceration rates, 1978-2004. Justice Quarterly 28, 174-201.

Terrill, W. (2005). Police use of force: A transactional approach. Justice Quarterly 22, 107-138.

Tillyer, R., Engel, R., \& Wooldredge, J. (2008). The intersection of racial profiling research and the law. Journal of Criminal Justice 36, 138-153.

Tonry, M. (2011). Less imprisonment is no doubt a good thing: More policing is not. Criminology \& Public Policy 10, 137-152. 
Tregle, B, Nix, J., \& Alpert, G.P. (2019). Disparity does not mean bias: Making sense of observed racial disparities in fatal officer-involved shootings with multiple benchmarks. Journal of Crime and Justice 42, 18-31.

Tyler, T.R. (2017). Procedural justice and policing: A rush to judgement? Annual Review of Law and Social Science 13, 29-53.

Tyler, T.R., Fagan, J., \& Geller, A. (2014). Street stops and police legitimacy: Teachable moments in young urban men's legal socialization. Journal of Empirical Legal Studies $11,751-785$.

Waddington, P.A.J, Stenson, K., \& Don, D. (2004). In proportion: Race, and police stop and search. British Journal of Criminology 44, 889-914.

Weisburd, D. (2015). The law of crime concentration and the criminology of place. Criminology $53,133-157$.

Weisburd, D., Hinkle, J., Famega, C., \& Ready, J. (2011). The possible "backfire" effects of hot spots policing: An experimental assessment of impacts on legitimacy, fear and collective efficacy. Journal of Experimental Criminology 7, 297-320.

Weisburd, D., Mastrofski, S.D., McNally, A.M., Greenspan, R., \& Willis, J.J. (2003). Reforming to preserve: COMPSTAT and strategic problem solving in American policing. Criminology \& Public Policy 2, 421-456.

Weisburd, D., \& Telep, C.W. (2014). Hot spots policing: What we know and what we need to know. Journal of Contemporary Criminal Justice 30, 200-220.

Weisburd, D., Telep, C.W., \& Lawton, B.A. (2014). Could innovations in policing have contributed to the New York City crime drop even in a period of declining police strength?: The case of stop, question and frisk as a hot spots policing strategy. Justice Quarterly 31, 129-153.

Weisburd, D., Wooditch, A., Weisburd, S., \& Yang, S.M. (2016). Do stop, question, and frisk practices deter crime? Criminology \& Public Policy 15, 31-56.

Wilson, O.W. (1957). Police Planning. Thomas Publisher.

Wilson, W.J. (1987) The Truly Disadvantaged: The Inner-City, the Underclass, and Public Policy. Chicago, IL: University of Chicago Press. 
Wheeler, A.P., Steenbeek, W., \& Andresen, M.A. (2018). Testing for similarity in area-based spatial patterns: Alternative methods to Andresen's spatial point pattern test. Transactions in GIS 22, 760-774.

Wooditch, A., \& Weisburd, D. (2016). Using space-time analysis to evaluate criminal justice programs: An application to stop-question-frisk practices. Journal of Quantitative Criminology 32, 191-213.

Worden, R.E. (1989). Situational and attitudinal explanations of police behavior: A theoretical reappraisal and empirical assessment. Law \& Society Review 23, 667-711.

Worden, R.E., \& McLean, S.J. (2017). Mirage of Police Reform: Procedural Justice and Police Legitimacy. Oakland, CA: University of California Press. 
Table 1: Example Areas

\begin{tabular}{rrr} 
Area & $\begin{array}{r}\text { Predicted } \\
\text { Crimes }\end{array}$ & $\begin{array}{r}\text { Percent } \\
\text { Minority }\end{array}$ \\
\hline A & 60 & $80 \%$ \\
B & 20 & $60 \%$ \\
C & 3 & $10 \%$ \\
\hline
\end{tabular}

Table 2: Variable Definitions

Variable Definition

$x_{i j}$ Decision variable to allocate proportion of resources to grid cell $i$ nested within precinct $j$

$n$ Total number of grids cells

$V_{i j} \quad$ Violent Crimes in grid cell $i$ nested within precinct $j$

$M_{i j} \quad$ Estimated probability of a minority stop within grid cell $i$ within precinct $j$ using multi-level logistic regression

C Threshold for constraining expected proportion of minorities to be stopped 

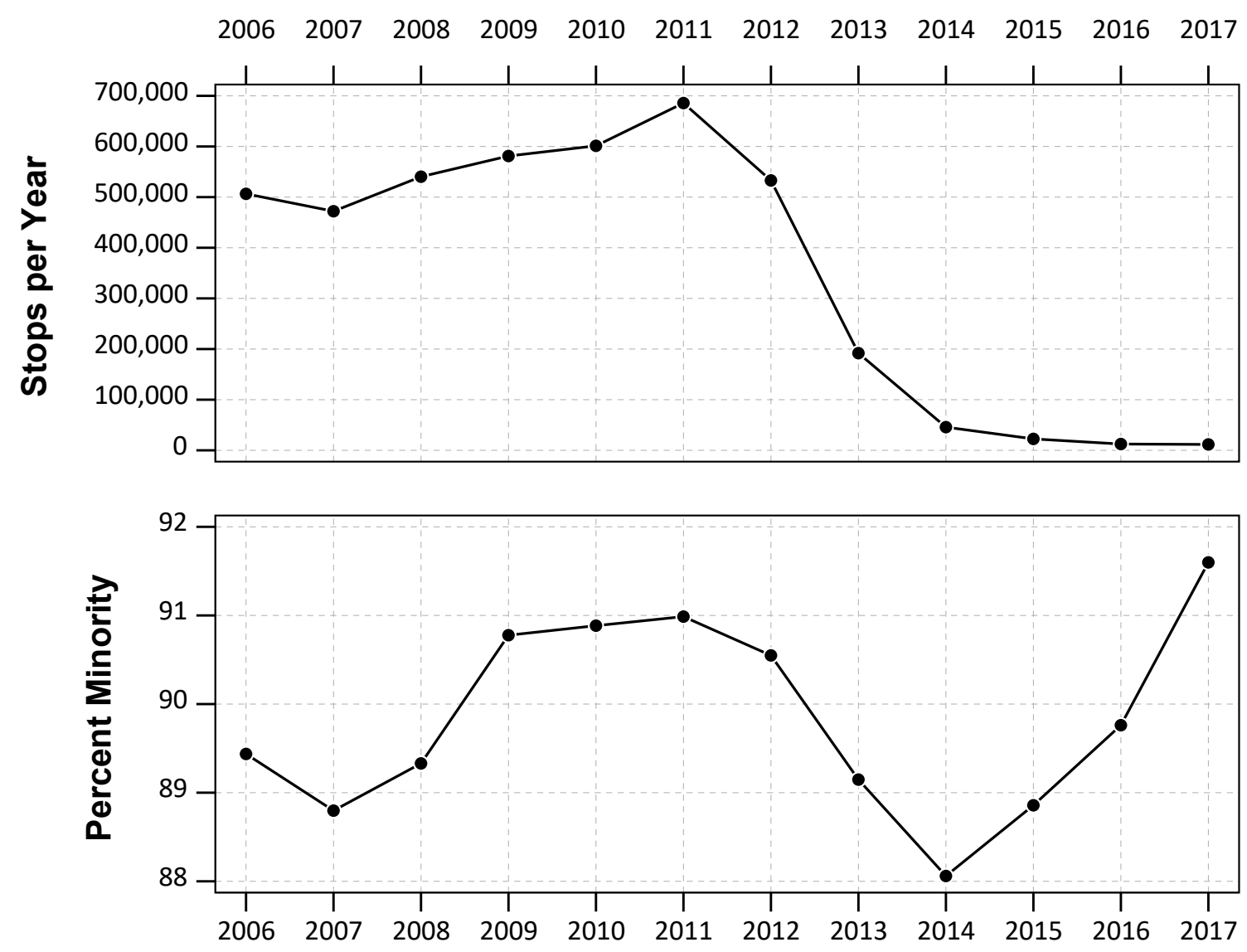

Figure 1: Pedestrian stops and the percentage of minority stops per year by the NYPD. 


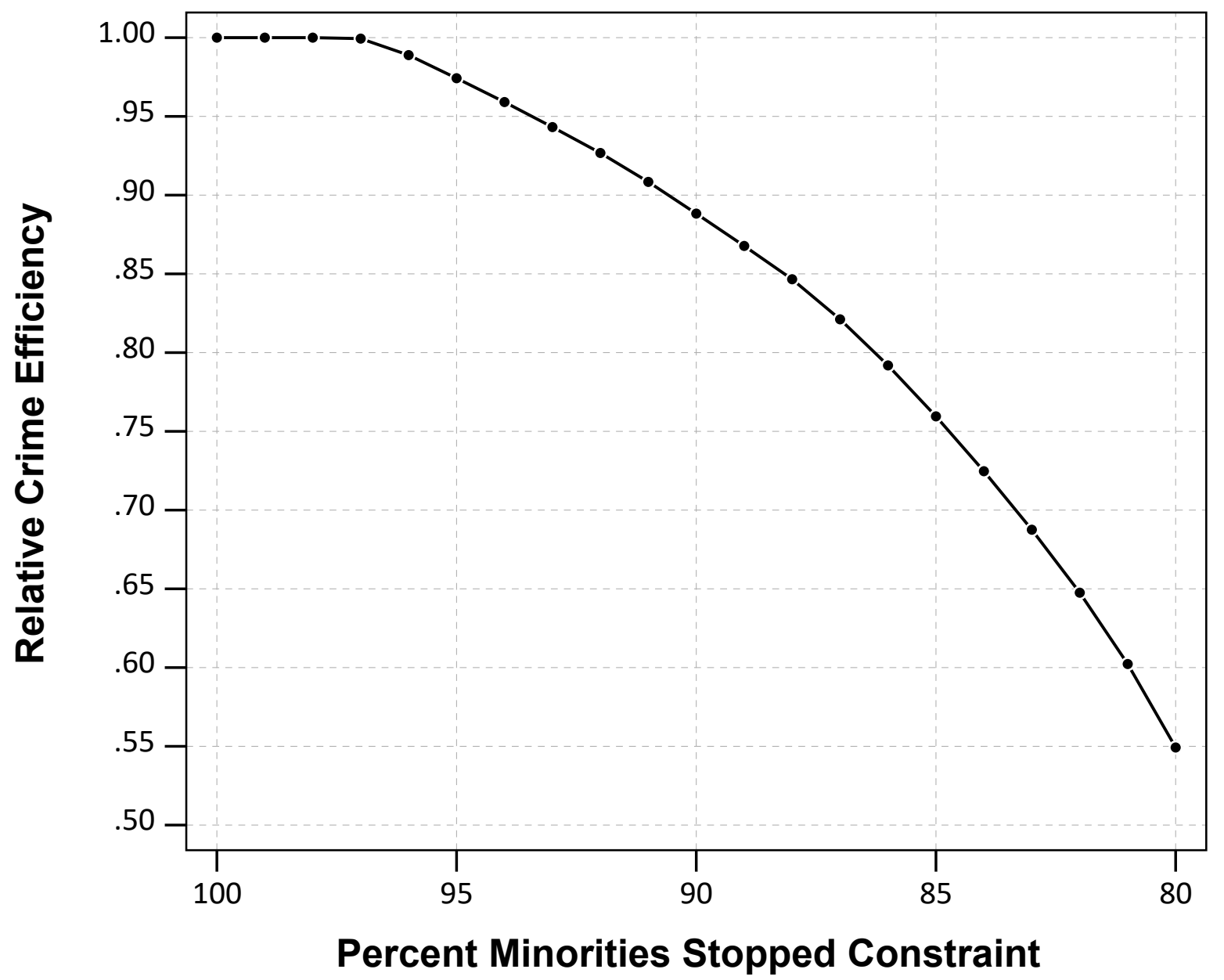

Figure 2: Relative decline in efficiency when targeting high crime areas, but progressively making a lower percentage expected minority's stopped constraint. 
100

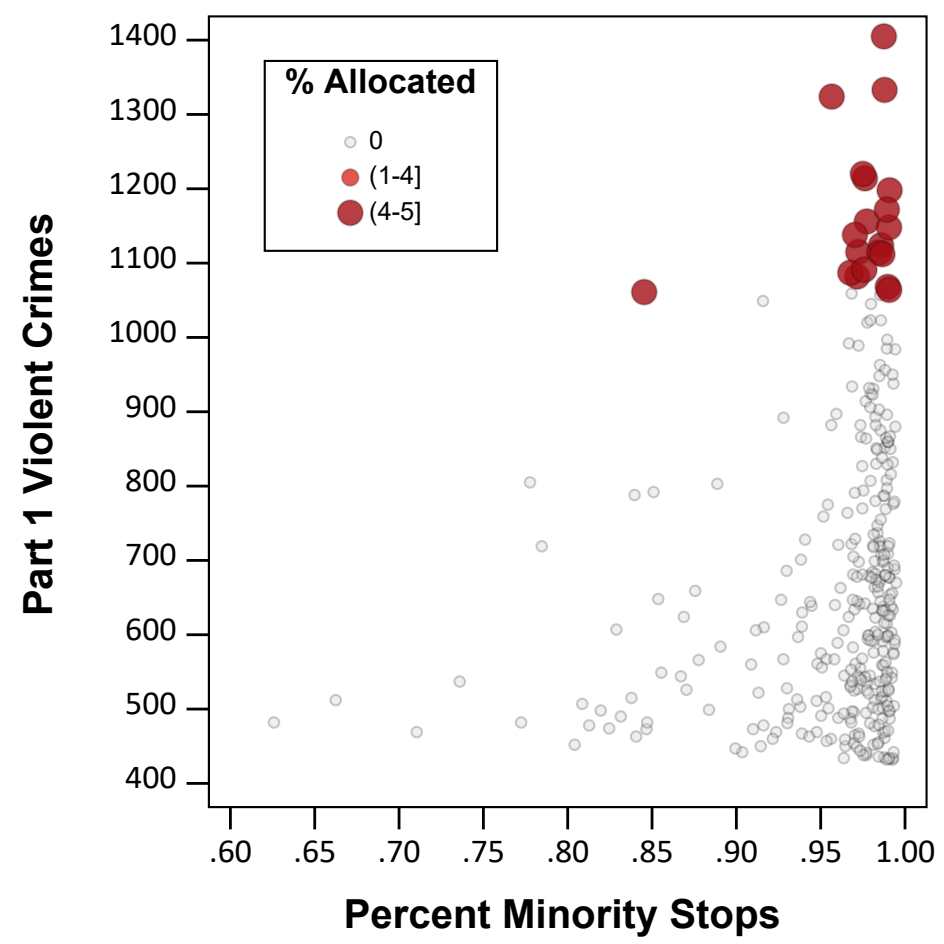

90

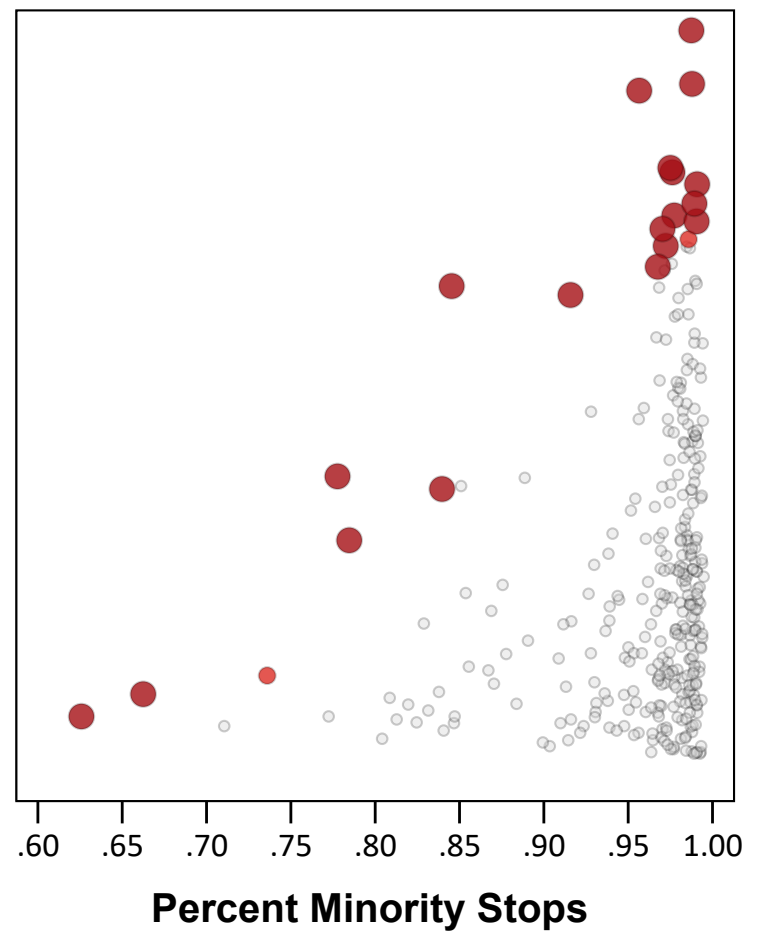

80

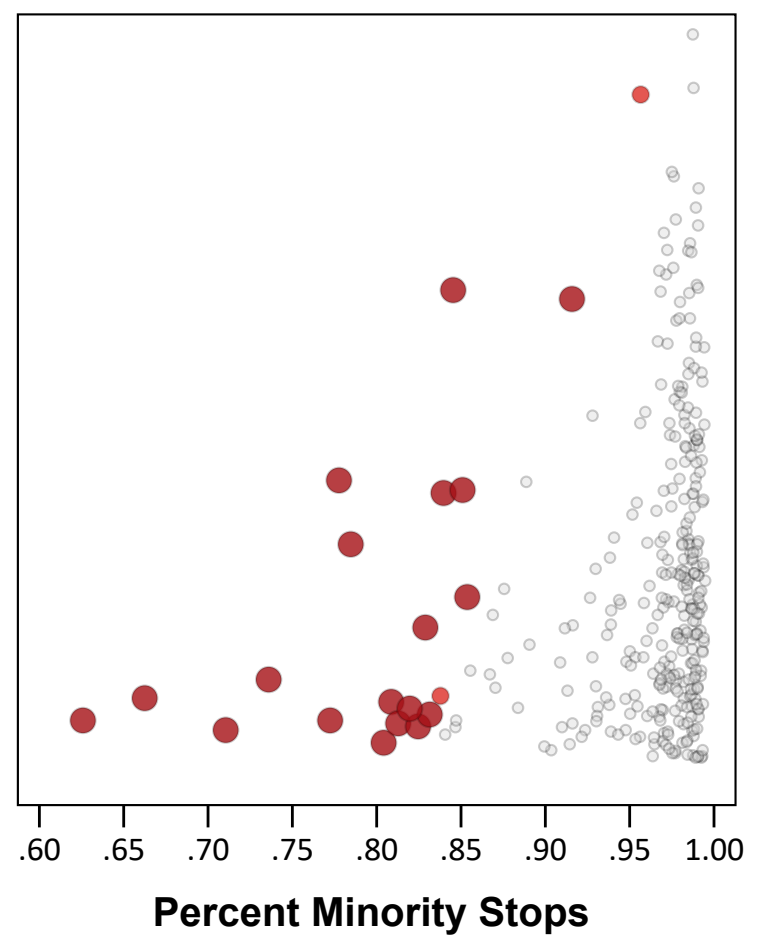

Figure 3: Scatterplot showing the relationship between the estimated percentage of stops that are minority and the number of Part 1 violent crimes. Colors and size of the points demarcate the proportion of resources devoted to each grid cell. Number above each panel depicts the proportion minority constraint, from $100 \%$ to $80 \%$. 


\section{Appendix A}

Appendix A provides an extension to the linear programming model in the paper to only select an integer number of locations, so is a mixed integer linear program. The function to be maximized is equivalent to that presented in the main paper, but the constraints are slightly different:

$$
\operatorname{Maximize}\left\{\sum_{i}^{n} x_{i j} \cdot V_{i j}\right\}
$$

Subject to the constraints:

1. $\sum_{i}^{n} x_{i j}=k$

2. $x_{i j} \in(0,1)$

3. $\sum_{i}^{n} M_{i j} \cdot x_{i j} \cdot k^{-1} \leq C$

The first constraint is that the sum of the decision variables needs to equal $k$. The second constraint is that the decision variables can only take on the values of zero or one. These subsequently mean an area is chosen or it is not chosen for the hot spots policing strategy, and that the researcher wants to choose a total of $k$ areas. The third constraint is the minority constraint, but is rewritten to note that if each hot spot gets the same amount of resources devoted to it, it will have $k^{-1}$ of the total resources devoted to that area. This is the same weighted proportion of minorities stopped constraint as in the main manuscript, just simply amended to take into account the decision variables are not proportions, but binary $0-1$ values.

I illustrate this with $k=10$, which shows similar patterns to the linear program in the main manuscript, just with fewer areas selected. Figure A.1 generates a relative efficiency chart, comparing the solution with no racial constraints to those with progressively more strict racial constraints, all the way to no more than $80 \%$ of the stops should be of minorities. This shows that 
with no race constraints the mean number of crimes within a chosen hot spot is over 1,200 , but this progressively diminishes to under 850 with a racial equity constraint of $80 \%$. This results in an efficiency of approximately $66 \%$ compared to the hot spots strategy with no constraints.

Figure A.2 shows a scatterplot of which locations are chosen. Similar to the main manuscript, choosing locations to best satisfy the racial equity constraint involves choosing the areas with the area with the lowest minority percentage - even if they have the lowest amount of crime, in an attempt to balance them out with the highest crime locations.

Figure A.3 shows this same scatterplot applied to the entire dataset without restricting the decision variables to just grid cells that have over 432 violent crimes in the time period. The only criteria is that a grid cell had to have at least one stop and one violent crime over the study period. A total of 2,798 grid cells meet this criteria. This illustrates that the procedure will tend to balance out high crime and high minority areas with very low crime and very low minority stopped areas, which is not necessarily consistent with hot spots policing. Thus the main analysis focuses on just areas that can reasonably be considered high crime areas due to the regular occurrence of violence. Figure A.4 shows the relative loss in efficiency though, which is not as extreme as what occurs when only considering the highest crime subset in Figure A.1. For example, at the $80 \%$ minority constraint, it only results in an efficiency reduction of $81 \%$, compared to the $66 \%$ efficiency at that same minority constraint among the only hot spots subset. 


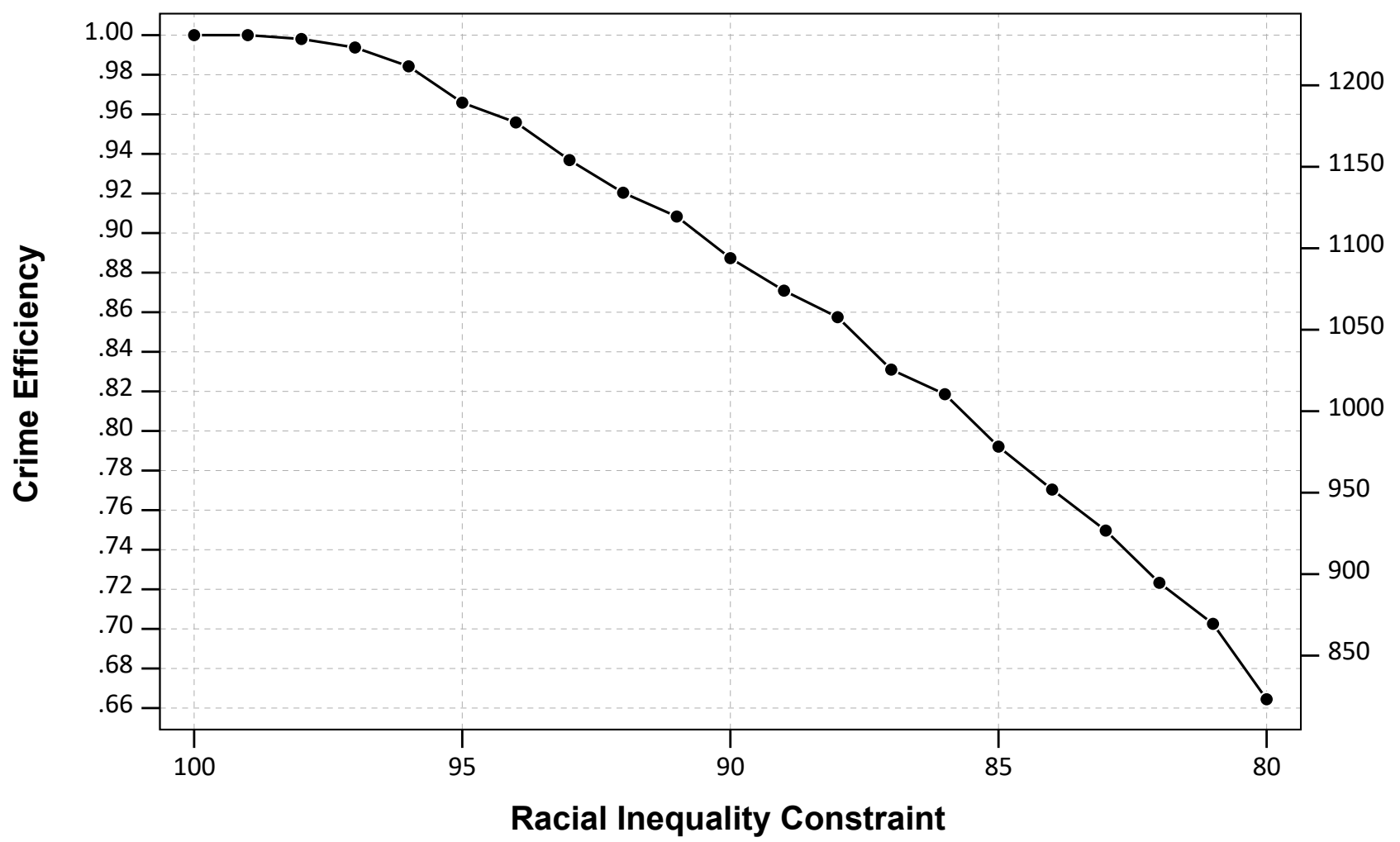

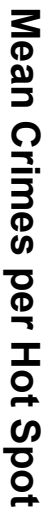

Figure A.1: Relative efficiency of targeting areas with more strict racial equity constraints. 

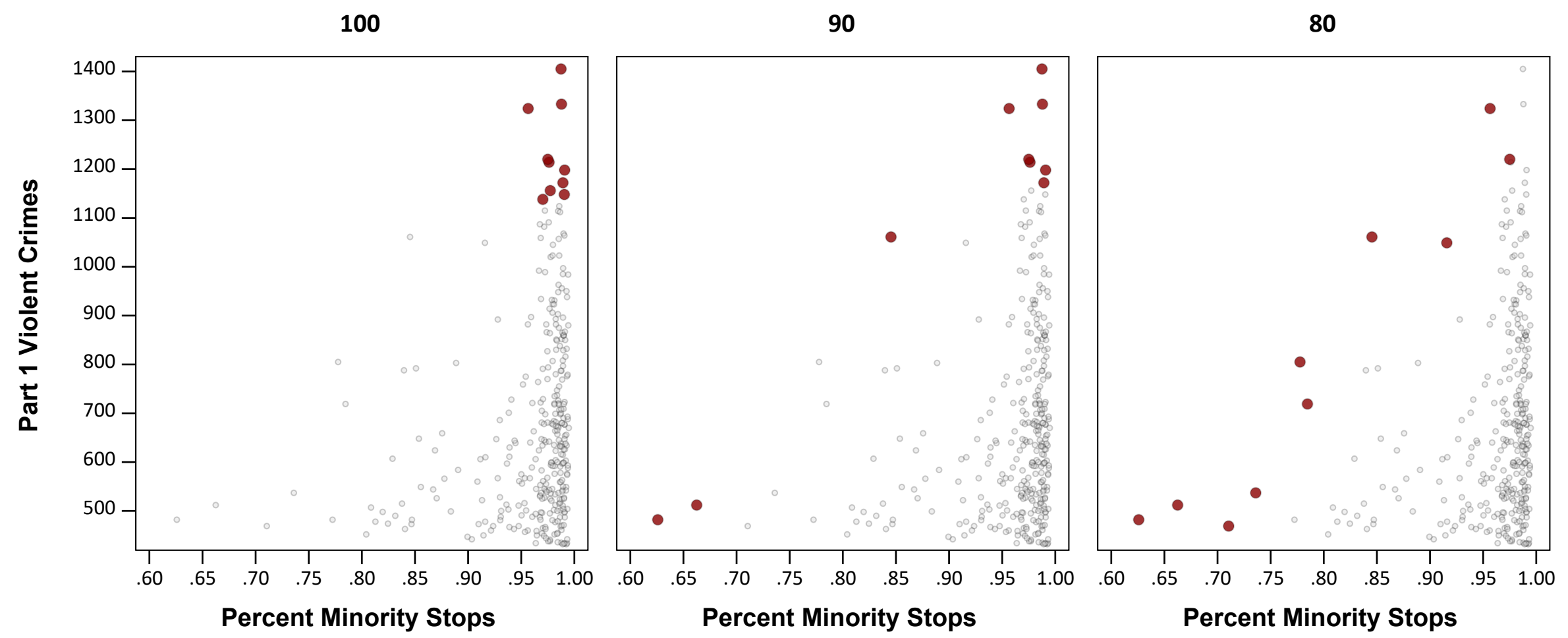

Figure A.2: Scatterplot showing the areas chosen (larger red dots) under no racial equity constraints (100), that the percent of minority stops needs to be $90 \%$ or lower (90), or that the percent of minority stops needs to be $80 \%$ or lower (80). 
100

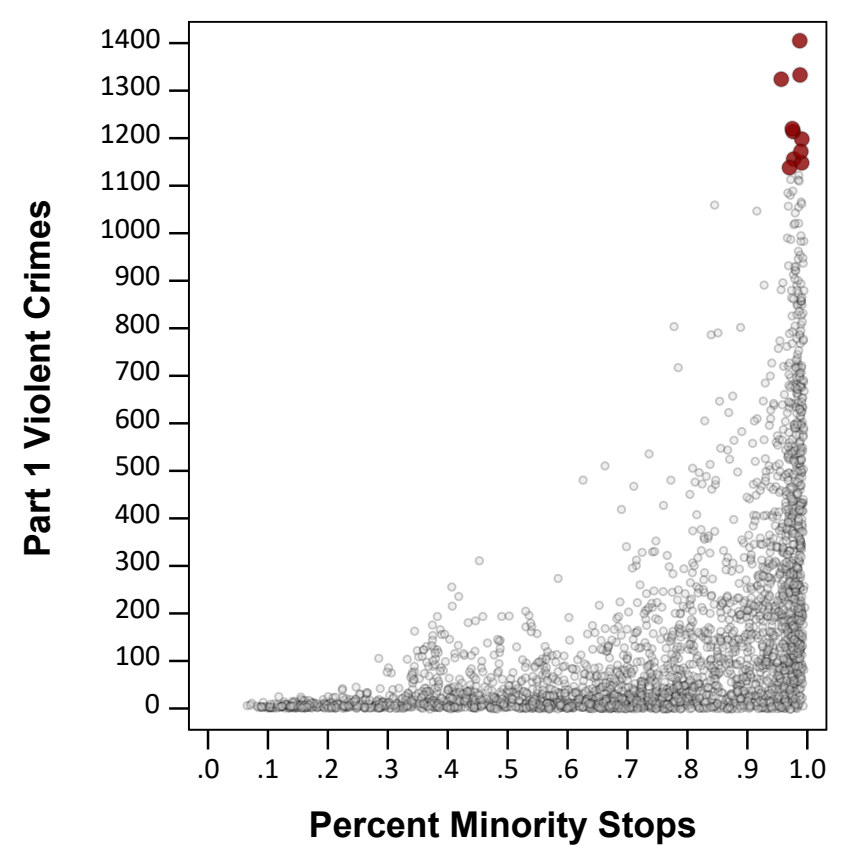

90

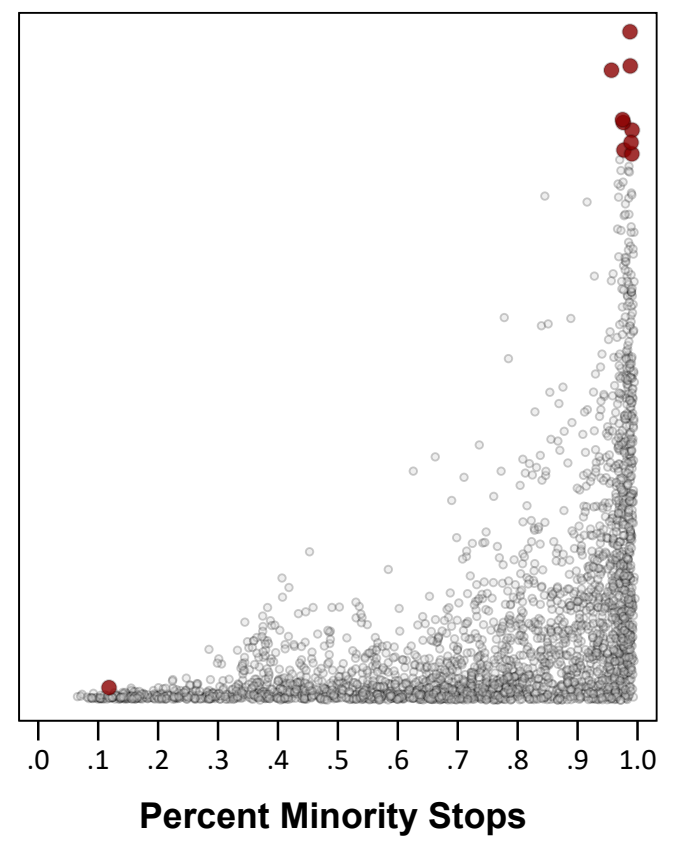

80

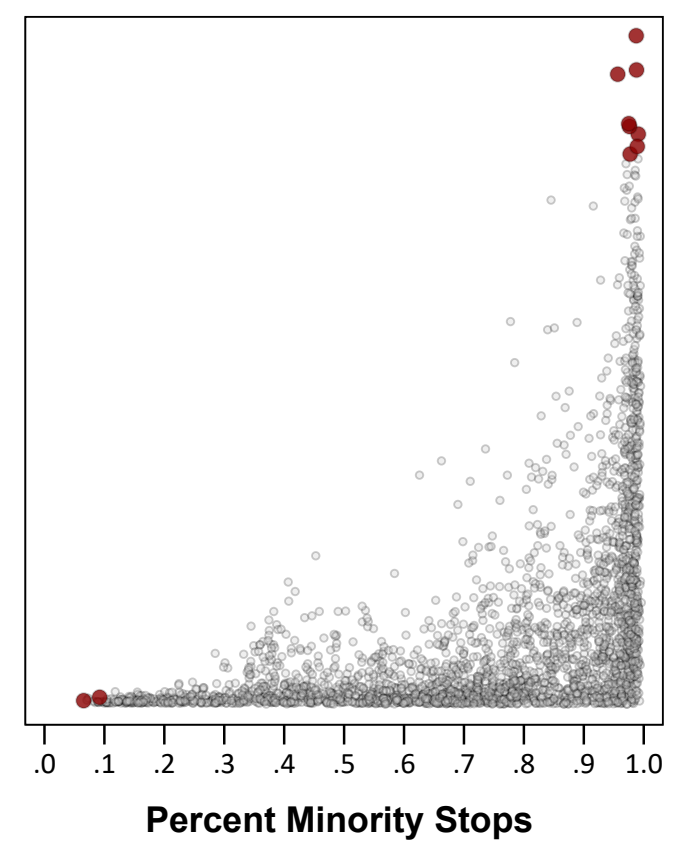

Figure A.3: Scatterplot showing the grid cells chosen when only restricting the sample to places with at least one violent crime over the study period. 


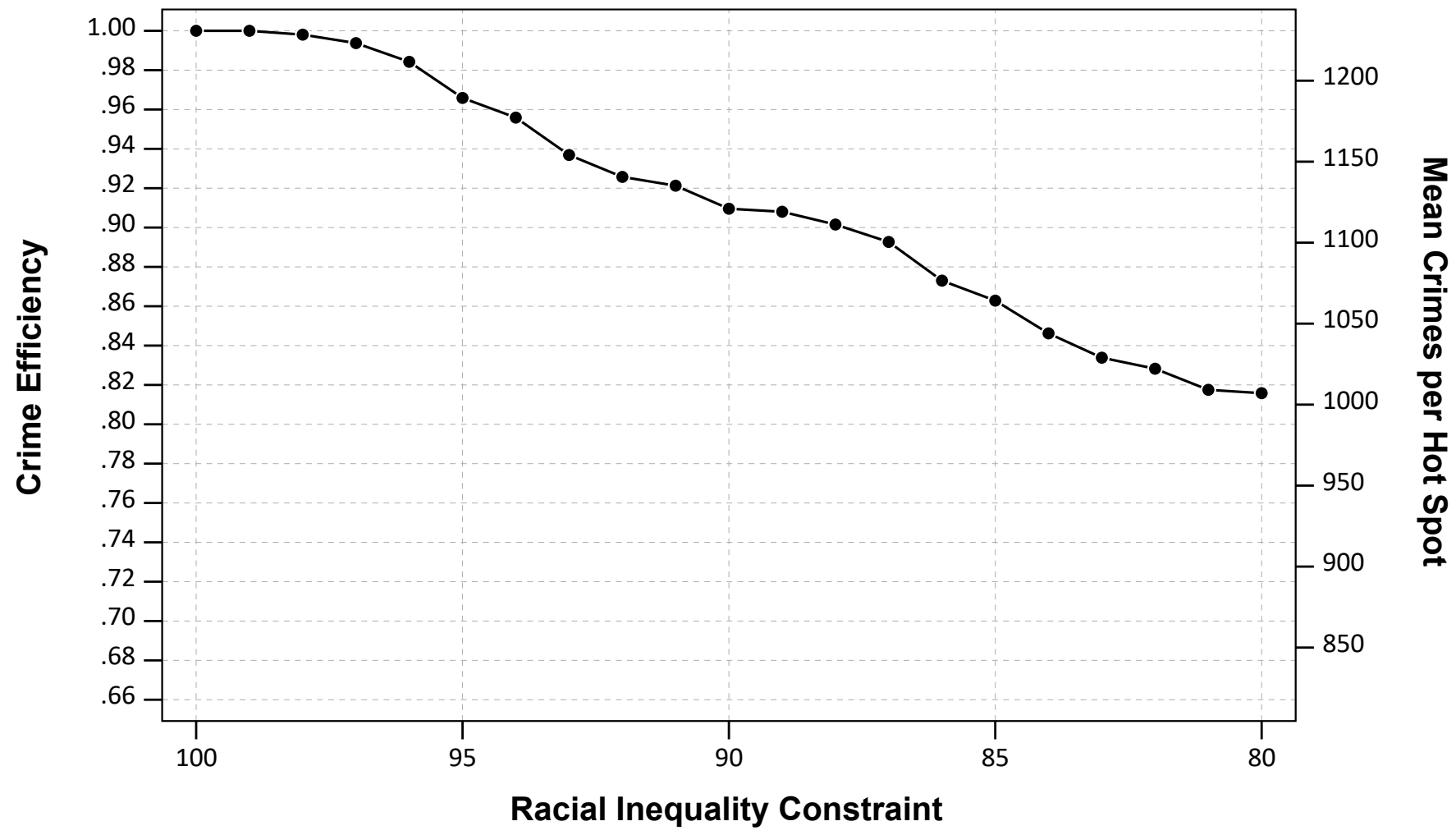

Figure A.4: Efficiency chart when choosing all grid cells with at least one violent crime over the study period. 


\section{Appendix B}

Figure B1 displays the spatial locations of those targeted hot spots under the three different racial constraints, along with the borough outlines in New York City. The grid cells that are outlined are those that have over 432 Part 1 violent crimes, and the grid cells colored in red are those that are selected under the progressively more strict racial equity constraints. Overall, the majority of grid cells are clustered in Brooklyn, the Bronx, and upper and lower Manhattan. There are no grid cells that meet this criterion in Staten Island, and only a few clusters within Queens.

For the strategy with no racial constraints, that is just selecting the top twenty high crime grid cells, results in the majority of selected hot spots in northern Manhattan and the Bronx. Only one grid cell is in Brooklyn, and only one grid cell is in lower Manhattan. For the strategy of only stopping $90 \%$ minorities, there is a number of grid cells now selected in lower Manhattan, but there are still several locations in upper Manhattan and the Bronx selected. The one location in Brooklyn also still remains. With the $80 \%$ racial equity constraint, almost all of the locations selected are now in lower Manhattan, with a just one location in upper Manhattan, and two grid cells selected in the Bronx. In general, this analysis suggests that targeting hot spots of crime in lower Manhattan may reduce the overall proportion of minorities stopped by the NYPD. 
100 No Racial Constraint

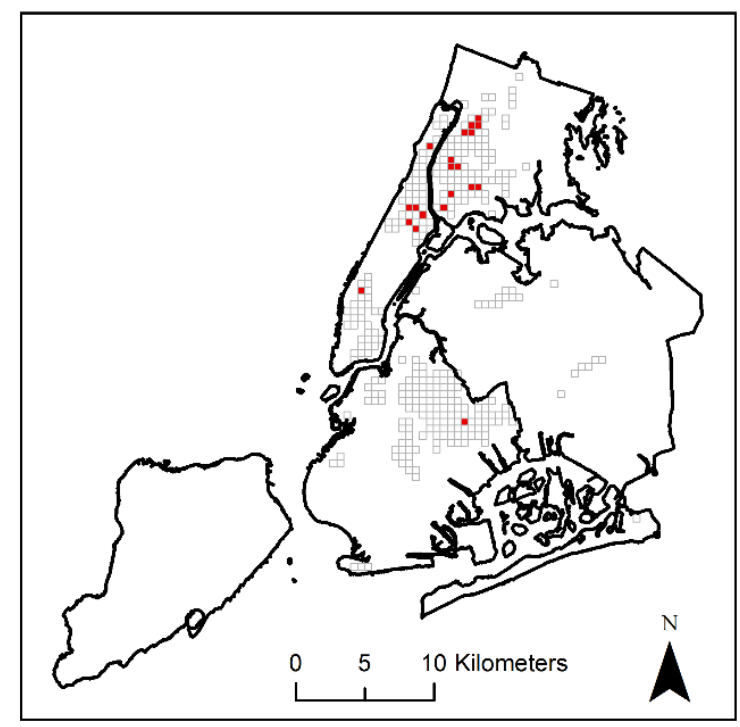

90 Racial Constraint

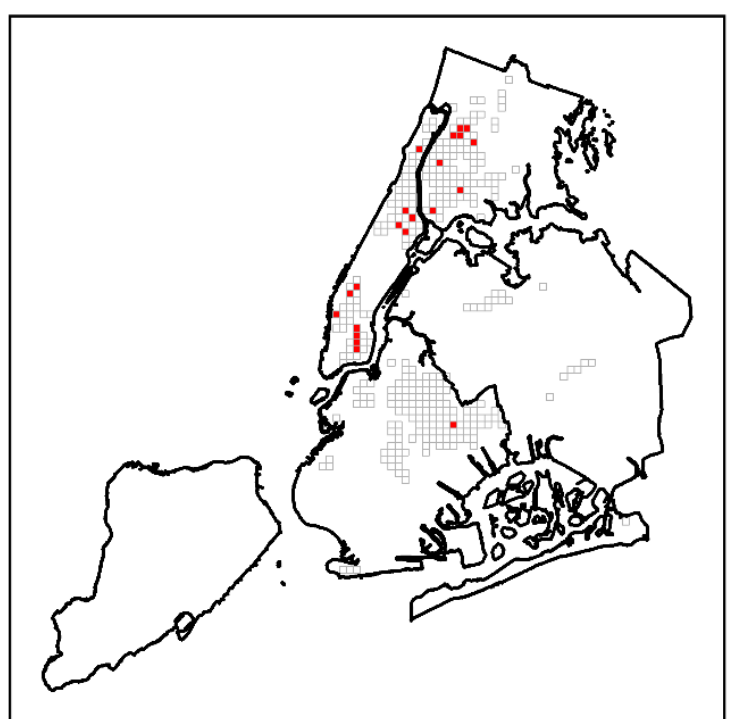

80 Racial Constraint

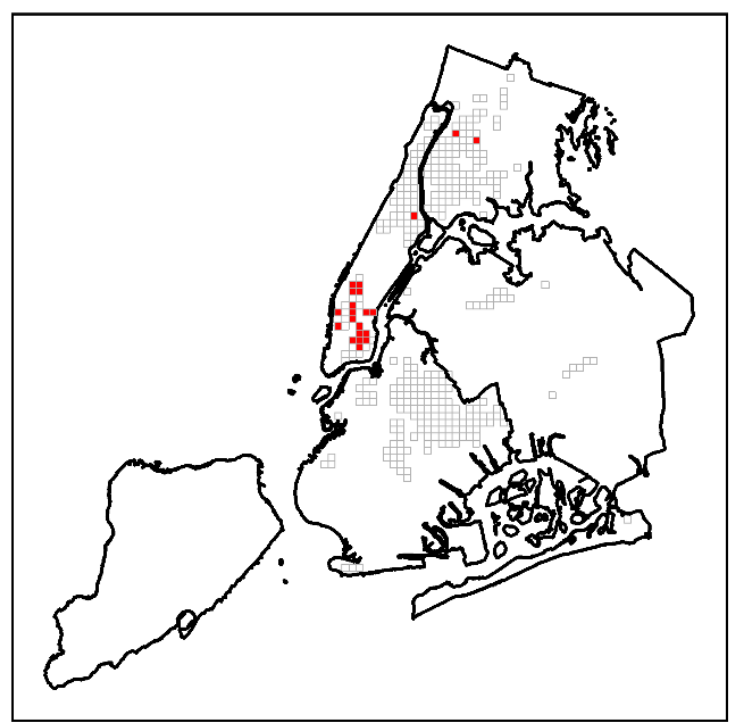

Figure B1: Map of allocated resources targeting high crime areas with no racial constraints versus map with a racial constraint of only stopping $90 \%$ or $80 \%$ minorities. Grey outlined areas with no color are those grid cells with more than 432 Part 1 violent crimes over the study period. Red cells are those that are selected as hot spots for each allocation strategy with differing levels of racial equity constraints. 